$27 \mid 2021$

Political Mobilizations of South Asians in Diaspora: Intertwining Homeland Politics and Host-Society Politics

\title{
Political Activism in Canada: When Tibetans in Toronto Enter into Local Politics
}

\section{Anne-Sophie Bentz}

\section{OpenEdition \\ Journals}

\section{Electronic version}

URL: https://journals.openedition.org/samaj/7449

DOI: $10.4000 /$ samaj.7449

ISSN: 1960-6060

Publisher

Association pour la recherche sur l'Asie du Sud (ARAS)

\section{Electronic reference}

Anne-Sophie Bentz, "Political Activism in Canada: When Tibetans in Toronto Enter into Local Politics", South Asia Multidisciplinary Academic Journal [Online], 27 | 2021, Online since 26 January 2022, connection on 15 March 2022. URL: http://journals.openedition.org/samaj/7449; DOI: https://doi.org/ $10.4000 /$ samaj.7449

This text was automatically generated on 15 March 2022.

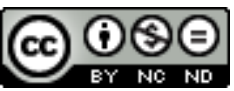

This work is licensed under a Creative Commons Attribution-NonCommercial-NoDerivatives 4.0 International License. 


\title{
Political Activism in Canada: When Tibetans in Toronto Enter into Local Politics
}

\author{
Anne-Sophie Bentz
}

My deepest gratitude goes to all the Tibetans I met in Toronto. Without their precious insights and their communicative enthusiasm, this article would simply not exist. I would also like to thank the three anonymous reviewers for some highly valuable suggestions, which opened up new directions for thinking about the political mobilization of migrants. I am no less greatly indebted to the Institut Convergences Migrations (IC Migrations) for participating in the funding of my field research in Toronto in September-October 2019, and to the Unité de Recherches Migrations et Société (URMIS) for funding the editing in English of this article.

1 The first time I encountered the name Bhutila Karpoche was in the Tibetan settlement of Majnu-Ka-Tila (India) in January 2019. I was waiting for my lunch in a Tibetan restaurant when I came across an article entitled "First Tibetan, Bhutila Karpoche Wins Election in Canada" in an old issue of the Tibetan Journal. This caught my attention in the light of a planned fieldtrip to Toronto later that year to investigate the political mobilization of Tibetans. If I wanted to understand how Tibetans could enter into local politics in Canada, this is where I had to start. Bhutila Karpoche, the incumbent Member of Provincial Parliament (MPP) for Parkdale-High Park, is a star not only in the more than 6,000-strong Tibetan community of Toronto (2016 Canadian Census), but for Tibetans across the world. She was also voted Toronto's Best Local Politician by Toronto Star readers, Toronto's Best MPP by NOW Magazine readers, and named one of Toronto's Most Inspirational Women of the year in 2019. ${ }^{1}$ I requested an appointment with her and came to Toronto in September 2019 armed with the promise of "a tentative informal meet/chat" given by one of her assistants.

2 Further enquiries led me to Kalsang Dolma, who had been a candidate for council in Parkdale-High Park (Ward 4) during the Toronto Election in 2018. She did not win, but she is one of those Tibetans who tried to enter into local politics and, as such, her experience is also worthy of attention. During my fieldwork, which coincided with the 
campaign for the 2019 Canadian Federal Elections, I heard of yet another Tibetan, Kalden Dhatsenpa, who was a candidate in Quebec (Longueuil-Charles-LeMoyne). His trajectory falls outside of the scope of this article, which focuses on Toronto, but he is nevertheless the latest proof of a trend started by Bhutila Karpoche.

The topic of this article is the political mobilization of Tibetans in Toronto. ${ }^{2}$ Where does their political interest come from? In what way are they active in local politics? Why do some of them become candidates? And what do they do when elected? Bhutila Karpoche is the most successful example of political involvement, after a career as a Tibetan activist, but other Tibetans have also gotten involved, albeit in different ways, in Canadian politics. My hypothesis about this transition from activism within the Tibetan community to activism in Canadian society is that Tibetans in Toronto who enter into local politics are already politicized.

4 I have already examined the process that led young Tibetans in Toronto to become involved in Tibetan issues (Bentz 2021). This is what I call an inward-looking type of mobilization, i.e. mobilization that is concerned with specifically Tibetan issues-the Tibetan community in Canada ("immigrant politics") or the cause of Tibet ("homeland politics"). What I propose to do now is shift the focus from ethnic/transnational politics to local politics and study mobilization focused on non-Tibetan issues ("political integration")-what I call an outward-looking type of mobilization.

5 To do so, I will briefly present my fieldwork, before framing my analysis through a series of theoretical perspectives on the political integration of migrants, in particular the Strategic Interaction Perspective (see, notably, Fligstein and McAdam 2011; Fligstein and McAdam 2012; Goodwin and Jasper 2012; Jasper 2006; Jasper and Duyvendak 2015). I will then turn to the historical and legal context of Tibetan migration to Canada and address Tibetan settlement in Toronto. Such a historical, geographical and theoretical contextualization will serve as the background to my analysis of the Tibetans' involvement in the local politics of Toronto. The perspectival shift from inward- to outward-looking mobilization leads me to foreground the careers of the two Tibetans who stood for office in Toronto, Bhutila Karpoche and Kalsang Dolma, to whom I add Gelek Badheytsang, a Tibetan blogger married to Kalsang Dolma who turned campaign manager in 2018, when Kalsang Dolma decided to run for office. I will briefly conclude with a reflection on how this particular case-study helps us expand our theoretical understanding of "strategic action fields" (Fligstein and McAdam 2011; Fligstein and McAdam 2012) or "arenas" (Jasper and Duyvendak 2015; see also Jasper 2006 and Jasper 2012 for earlier reflections on "arenas").

\section{Conducting Fieldwork during a Political Campaign}

6 I conducted my fieldwork in September-October 2019 in Parkdale-the "Little Tibet" neighborhood of Toronto. ${ }^{3}$ The timing was particularly interesting: the Canadian Federal Elections were coming up (October 2019), which meant intense campaigning activities all over the country. The context in Toronto was therefore quite out of the ordinary and, as far as I could see, conducive to an increase in the political activities of Tibetans there.

There are three main political parties in Canada: the right-leaning Conservative Party, current Prime Minister Justin Trudeau's center-left Liberal Party and, to the left, the New Democratic Party (NDP). Tibetans in Canada do not necessarily align ideologically 
with any one of these. They tend instead to support politicians who are critical of China or who have been vocal about the cause of Tibet and/or the Dalai Lama. This had led them to praise former Prime Minister Stephen Harper for making the Dalai Lama an honorary citizen of Canada in 2006 and to criticize current Prime Minister Trudeau for siding with China in 2013. Things are slightly different for Tibetans in Toronto. Many of them are unhappy with current Conservative Mayor John Tory and Ontario Premier Doug Ford, and the fact that Parkdale is a progressive neighborhood is no incentive to lean towards the Conservative Party either. The recent political campaign left those who live in Parkdale divided between two choices: Liberal incumbent candidate Arif Virani and New Democratic Party (NDP) challenger Paul Taylor. Arif Virani's strong legacy in Parkdale appealed to many Tibetans (Interviews with Samten, Thupten and Choedak), but Bhutila Karpoche's siding with fellow New Democratic Party (NDP) member Paul Taylor was an incentive to vote for the new candidate. If it can be assumed that those Tibetans who work for political parties usually do so out of ideological reasons, it clearly appeared in the fieldwork that other Tibetans were just as concerned with a candidate's legacy and views on the Tibet issue and on life in Parkdale/Toronto, as with a party's platform.

8 I had decided to target two types of Tibetans during my fieldtrip, Tibetan leaders and Tibetan restaurant-owners, to get a sense not only of how socially and politically active the Tibetan community in Toronto was, but also of the kind of role some of the more visible Tibetans in Parkdale were playing. I conducted sixteen in-depth interviews based on an open-ended questionnaire. ${ }^{4}$ There were four specific questions about local politics: "Are you interested in local politics?", "If you have a right to vote, did you vote in the last elections?", "What do you think of the two candidates of Tibetan heritage, i.e. Bhutila Karpoche (MPP Ontario for the New Democratic Party [NDP]) and Kalsang Dolma (Toronto City Council Candidate, Parkdale-High Park)?", and "Did you vote for any of them?" The availability and the attentiveness of many of the Tibetans I encountered greatly helped me conduct my fieldwork. It might have helped that I had done a lot of research on Tibetans in India in the past; it might also have helped that most of my interviewees had never met a researcher before. ${ }^{5}$ However, I was still surprised by the feeling of mutual trust that developed very quickly between us, which led these Tibetans to tell me very personal stories and to invite me to various events organized or joined in by Tibetans.

9 Bhutila Karpoche, who cancelled our planned meeting at the last minute, stands as an exception. The timing of my request may not have been right for her, as, while on maternity leave, she was also actively involved in the ongoing political campaign. However, further attempts to reschedule a meeting were all denied, on the ground that she did not want to be part of any research project ever. I would argue that this may have to do with the content of my research, as well as her own highly promising political career. I could not secure a meeting with Kalsang Dolma either. I learnt from Gelek Badheytsang that, when my fieldwork was underway, she was of poor health, as well as very busy, having resumed all her previous commitments in the Parkdale community. The motives behind Kalsang Dolma's disinclination to be interviewed are, in my view, quite different from Bhutila Karpoche's. I put it down to a lingering campaign fatigue, a willingness to turn the page back to her social work in Parkdale and a feeling that it might have been too early still to reflect serenely on this experience. 
10 I cannot predict how an interview with Kalsang Dolma would have gone, but I am fairly confident that, given her cautiousness, I would not have learnt anything that I did not find elsewhere, had I been able to meet Bhutila Karpoche. In any event, I decided to make the most of my two failed meetings, by filling in the blanks with my other interviews and through a wealth of additional primary material. I started with the official website of MPP Karpoche ${ }^{6}$ and the official Facebook page of candidate Kalsang Dolma. ${ }^{7}$ t then looked at two interviews with Kalsang Dolma on Radio Free Asia during the campaign for the Toronto Election in $2018 ; 8$ an older interview of Kalsang Dolma on Voice of America-Tibet; 9 and campaign material for the 2019 elections, where neither Bhutila Karpoche, nor Kalsang Dolma were candidates. I also engaged in a systematic study of articles in newspapers and magazines mentioning one of the three Tibetans under study. ${ }^{10}$ This material, which is quite exhaustive, enabled me, among other things, to gather factual information; to address the self-presentation of, as well as the views held by others on, Bhutila Karpoche and Kalsang Dolma; and to investigate the support extended by Bhutila Karpoche, Kalsang Dolma and Gelek Badheytsang on various issues.

\section{Theoretical Perspectives on the Political Integration of Migrants}

11 How well are Tibetans integrated into the political life of Toronto? To answer this question, we first need to ask a more general question: how do we measure the political integration of migrants? I would suggest that this question can best be answered by drawing on theoretical inputs from Social Movement Studies and Diaspora Studies.

The first thing to do, however, is to define political integration. Should political participation be limited to conventional forms of political life in the host country, such as voting on referenda, becoming members of political parties and voting or running for elections? A more inclusive definition has been offered to take into consideration non-conventional forms of political participation, i.e. protests, demonstrations, sit-ins, political strikes, hunger strikes, civil disobedience and boycotts, which are sometimes referred to as civic participation (Gabrielli, Gsir, and Zapata-Barrero 2017). Conventional and non-conventional forms of political participation could thus serve as indicators of the political integration of migrants in the host country. Not only that, political integration is often seen as a process beginning with civic participation, before migrants engage in political participation. They move from political apathy to informal mobilization over specific issues, then to more formal modes of association; this is how they end up participating in representative politics, which entails not just electoral participation but also activism in party politics; and this, in turn, ultimately leads to the election of councilors of ethnic minority background on city councils (Garbaye 2005:2-3).

13 The idea of a process of political integration is in line with the starting point of this article, which revolves around the hypothesis that Tibetans in Toronto who enter into local politics are already politicized. I would add that, in the Tibetan case, the civic participation phase can be further divided into two stages: a first stage specifically concerned with Tibetans issues and a second stage that moves on to embrace local, national or global issues. 
14 The next question is: where do migrants get politically integrated? The context of political mobilization has been one of the most debated topics in Social Movement Studies since the 1980s. Of specific interest is the relational shift which, at the beginning of the 2000s, made the context, or Political Opportunity Structure, converge with the protester's agency into what is sometimes referred to as a Strategic Interaction Perspective. This was presented as a solution to the limitations of the structure/agency problem (McAdam, Tarrow, and Tilly 2001). Such a shift enables us to consider that the migrants' political integration happens in "strategic action fields" (Fligstein and McAdam 2011; Fligstein and McAdam 2012) or "arenas" (Jasper 2006; Jasper 2012; Jasper and Duyvendak 2015), and thus to stress the importance of the migrants' purposeful and strategic action in a context of interaction with many other strategic players. It is thanks to these interactions that migrants can become "active immigrants" or "highly active immigrants" (see Zapata-Barrero and Gropas 2012 for the former and Vogel 2008 for the latter), i.e. not passive individuals, workers, or merely receivers of social services, but rather agents who can participate as citizens in the societies of either, or both, host and home countries.

The distinction between host and home countries is all the more important here as the context should not be limited to the host country. Eva Østergaard-Nielsen (2003) argues that, for many migrants, the relevant political opportunity structure affecting mobilization is not necessarily limited to that found in the receiving context, but often comprises that of the sending context (see also Gabrielli et al. 2017). Our focus may be on Canada, where the Tibetans' political integration takes place, but an analysis of the Tibetans' agency would be incomplete if the role of the Tibetan government-in-exile based in Dharamsala (India) was not also taken into account. A government-in-exile is often regarded as a third party in the distinction between host and home countries. However, I would argue that the Tibetan government-in-exile somehow also plays the role of a home country, as envisioned in both Diaspora Studies and Social Movement Studies. Indeed, the Tibetan government-in-exile works as a proxy home country, with which Tibetans entertain some of the citizen-style relations other migrants have with an actual home country (McConnell 2016). It would therefore be useful to distinguish between a homeland, Tibet, with which Tibetans worldwide have developed an idealized relationship, and a sending context (to retain Eva Østergaard-Nielsen's expression [2003], which I find more appropriate than home country) that can be subsumed by the Tibetan government-in-exile, whether Tibetans come from India or Nepal, as is the case with the vast majority of Tibetans in Canada. I will therefore follow Eva Østergaard-Nielsen's lead and consider that the Tibetans' participation, be it inward- or outward-looking mobilization, depends not only on the receiving context, Canada, and on the specific characteristics of Tibetan migrants, but also on the sending context-in our case, the Tibetan government-in-exile.

In fact, since the 1990s, Tibetans in the West are meant to use Western countries to promote the cause of Tibet; to that effect, the Tibetan government-in-exile has consistently sustained the political integration of Tibetans in (mainly) Europe and North America. While Tibetans in South Asia have been asked to remain stateless and to refrain from adopting Indian, Nepalese, or other citizenships (McConnell 2016:13642), Tibetans in the West have been encouraged to adopt the citizenship of the country of residence (Hess 2009:8-9). It is hoped that, once well settled not just as legal aliens but as citizens, Tibetans in Europe and North America will be able to make use of the 
openness of the political context to advance the cause of Tibet by organizing protests and engaging in lobbying activities or by becoming members of political parties and, even, running for election. Tibetans in the West are thus regarded as potential "ambassadors" of Tibet (Hess 2009), that is, not as "official" ambassadors, as this role has been assigned to the Offices of Tibet worldwide, but as strong supporters of the cause of Tibet. This shows that the Tibetan government-in-exile considers the context in the West to be more appropriate for mobilization than the South Asian context. All the Tibetans I met in Toronto were either Canadian citizens or had started the citizenship process. However, political integration does not stop at citizenship, and Tibetans in Toronto undergo a thorough process of politicization to become "ambassadors" for Tibet (Bentz 2021). This, I would argue, is another case where "exile Tibetans are contributing to a future Tibetan society through immersion and participation in a democratic country" (Hess 2009:9-Julia Hess is talking about the United States).

What is at play is "long-distance nationalism" (Anderson 1998) or "transborder nationalism" (Brubaker 2010): the Tibetan government-in-exile is engaging in an "external politics of belonging" to offer Tibetans in Toronto "new forms of external membership" (Brubaker 2010:77), while Tibetans in Toronto are then expected to become "ambassadors" of Tibet. This idea that home governments can view emigrants as resources is not new (Hein and Vang 2015; Itzigsohn 2000) and leads to the debated question of dual loyalties.

Are political relations with the home country a facilitating or limitative factor for the integration of migrants in the host country? Many researchers insist on the compatibility of transnational political activities oriented towards the home country and political integration in the host country, sometimes even arguing that transnational practices foster migrants' engagement in host-country politics (Morales and Morariu 2011; Portes 1999; Portes, Escobar, and Arana 2008; Vertovec 2003). Political skills and capital, as well as the mobilizing capacity of transnationally-engaged migrants, are seen as transferable and civic activities oriented towards the home country are viewed as the first step of political integration. In fact, seeing political integration as a process involving first a civic phase, which starts with concerns targeted at ethnic/transnational issues and is followed (but not superseded) by an involvement in local, national and global issues, is one way of solving the dual loyalties problem. In the Tibetan case, it can be argued that the very role the government-inexile expected Tibetans in Canada to play, that of being "ambassadors" of Tibet, was instrumental in the exceptional political integration of Tibetans in Toronto. By asking them to use all means available-i.e. both non-conventional and conventional forms of political participation-to support the cause of Tibet, the Tibetan government-in-exile was in effect encouraging them to become fully integrated politically in Canada.

\section{Entering a New Field: Tibetan Migration to Canada}

19 The origins of the Tibetan diaspora coincide with the Dalai Lama's own flight to India in 1959, following the Tibetan national uprising in Lhasa earlier that year. Tens of thousands of Tibetans left Tibet in the following months and years, seeking refuge in India, Nepal and, to a lesser extent, Bhutan. The last census conducted by the Tibetan government-in-exile estimates the Tibetan diaspora at 128,000 , with a vast majority 
still residing in camp-like settlements and scattered communities in India and Nepal (Planning Commission 2010). For decades, Tibetans have sought to build a strong Tibetan community in exile, under the leadership of the Dalai Lama and the Tibetan government-in-exile. I have argued elsewhere that the role envisioned for the camplike structure of the settlements, among other things preserving and promoting a Tibetan national identity, has long prevented the Tibetan government-in-exile from encouraging South Asian Tibetans to resettle in a Western country (Bentz 2010). This explains why, apart from a few exceptions, including one in Canada, Tibetans have remained in South Asia. This started to change in the 1990s with the Tibetan U.S. Resettlement Project (TUSRP). ${ }^{11}$ It has been argued that the project, which marks the expansion of the diaspora beyond South Asia, has initiated for Tibetans in India and Nepal a craze of "occidental longing" (Hess 2006:88). Tibetan migration to Canada, which picked up in the early 2000s, can be seen as part of that process of further diasporization. As newly migrated Tibetans, who were not part of the initial project, started facing a number of obstacles in the United States, notably regarding recognition as legal aliens, Canada increasingly appeared like a better option to start a new life.

This idealized image of Canada as a welcoming country is indeed backed up by the country's attitude towards migrants and refugees. Canada's migration policy became particularly benevolent towards non-European migrants after the Second World War. The implications for migrants are manifold. To start with, it is relatively easy to obtain the status of a legal alien, and, subsequently, to become a permanent resident in Canada. This, in turn, has more practical implications, such as access to health and social benefits, as well as the job market. Just like migrants, refugees can count on Canada's benevolence. Canadian refugee law has historically been more liberal than the 1951 Geneva Convention. Refugees can receive protection either by making a claim from within Canada or at a port of entry ("inland processing") or through Canada's resettlement and sponsorship programs ("overseas processing") (Bradley 2010:389-91). Tibetans, who were one of the first non-European refugee groups to arrive in Canada (Logan 2010; MacPherson, Bentz, and Ghoso 2008; Raska 2013), have benefitted from the liberality of the Canadian refugee regime in both types of processing.

21 Pressed by the Dalai Lama and the High Commissioner for Refugees (UNHCR), Canada agreed in July 1970 to resettle a small number of Tibetan refugees living in India. The first Tibetans who arrived in Canada in the early 1970s, via the Canadian-led Tibetan Refugee Program, settled successfully, but did not start a migration trend and the number of Tibetans in Canada remained low for decades (Logan 2010; Raska 2013). There was no other program of this kind for Tibetans until the 2010s, when Canada agreed to take in 1,000 stateless Tibetans living as refugees in Arunachal Pradesh (India) (Citizenship and Immigration Canada 2012). ${ }^{12}$ The 1,000 Project started in November 2013 and was concluded in July 2018. The Tibetans who came through this project, just as the first Tibetans from the Tibetan Refugee Program, went through "overseas processing" and were granted a "permanent resident" status before coming to Canada.

Most of the Tibetans I met were not part of either of these two programs, which account for only a small proportion of Tibetans in Canada. As pointed out earlier, an influx of new Tibetans, which was not part of any scheme, started in the early 2000s. Many Tibetans had decided to leave the United States at that time: Canada was perceived as a better location to settle down, not only because chances to get 
recognized as a refugee were higher, but also because access to full health and social benefits was easier. This was the beginning of a new migration trend: the Tibetan population in Canada has been the fastest growing Tibetan population in the diaspora ever since. Many of these Tibetans settled, and still settle in Toronto (Logan 2010:39-40; MacPherson et al. 2008; McGranahan 2018). These were, by and large, the Tibetans I interviewed.

It had been relatively easy for them to obtain refugee status, and, subsequently, permanent residency in Canada, as well as Canadian citizenship-from what I understood, the acceptance rate for Tibetans as refugees was 100\% (Interview with Tashi). This may sound surprising, but can be explained by Canada's decision to treat refugees as groups after the Second World War (Batarseh 2016). This policy explains the acceptance of the two Tibetan refugee programs, but also the success of the Tibetans coming through "inland processing." The only thing they have to do to be recognized as refugees is prove they are Tibetan (Interview with Tashi; see also McGranahan 2018:373). While this policy has attracted many Tibetans to Canada, including Tibetans living in the United States, access to various health and social benefits, as well as employment possibilities certainly works as an additional, if not a central, incentive.

Many of them live on a welfare allowance for the first few months or years, sometimes pooling several allowances together to secure rent for a flat (Interview with Tashi), but most of them are also keen to find a job in a country where, it is said, employment opportunities are aplenty. In Toronto, Tibetans usually start with petty jobs, in warehouses or at the Ontario Food Terminal, before starting a small business-the most popular choice being a restaurant (Interviews with Samten, Tashi and Karma).

It has been noted that, for Tibetans, "Canada is meaningful as a place where one can live, thrive, and even sink roots" (McGranahan 2018:375). Indeed, the institutional setup of Canada helps Tibetans, among other migrants and refugees, to become fully integrated citizens. Canada provides them with a legal status, social and health benefits, as well as (usually) a job. They have access to social rights and, with formal citizenship, they acquire political rights-all of these rights have been identified as the main attributes of formal and substantive citizenship (Marshall 1964). This is all the more important as it has been acknowledged that living as a citizen, or as a soon-to-be citizen, can encourage migrant activism (Gropas 2008).

What, then, is Canada's function? If we follow a Strategic Interaction Perspective, Canada is a field, i.e. "a socially constructed arena within which actors with varying resource endowments vie for advantage" (Fligstein and McAdam 2011:3), ${ }^{13}$ which Tibetans both move through and engage with. But it is not just any field: Canada, as a state field, can be regarded as a broader field environment that is both proximate to and vertically linked with all the other fields Tibetans in Canada engage in. ${ }^{14}$ Also, some fields are very much like structures, i.e. relatively stable and difficult to change, so that people must adapt themselves to these fields, much as the structure of a house forces us to walk through doors rather than walls (Jasper 2012:12). It is no surprise that the archetypical example of such a field is the institutional political structure. I have looked in detail at the institutional set-up of Canada to conclude that the legal and social rights provided to Tibetans are particularly beneficial to the development of political activism. This is all the more important as Canada, the broadest field Tibetans both move through and engage with, works as some kind of superstructure. 

Tibetans were able to become activists-one also needs to look at the local micro-level to get a more precise picture of what the host-country context is made up of, that is, to add another important field in which Tibetans interact.

\section{Settlement in Parkdale - Toronto}

Most of the Tibetans who came to Canada settled down in Toronto, so much so that Toronto now stands apart as the biggest area of Tibetan settlement outside South Asia. Out of the 8,040 Tibetans living in Canada, 6,035 live in the Greater Toronto Area, including 5,430 concentrating in Toronto City (2016 Canadian Census). The influx of new Tibetans in the early 2000s started a chain migration process. The more Tibetans come to Toronto, the more Toronto attracts new Tibetans. And these new Tibetans tend to converge on Parkdale.

Parkdale, known as the "Little Tibet" of Toronto, is home to 2,360 Tibetans (2016 Canadian Census). Located in West Central Toronto, it is well connected to downtown Toronto by the Gardiner Expressway and two major streetcar lines-King Street and Queen Street. It is further broken down into North and South Parkdale, with Queen Street as the dividing line.

South Parkdale is where most of the Tibetans live. There, Tibetan presence in the highrise buildings is discrete but unmistakable, with prayer flags hanging from balconies. However, the "Little Tibet" character of the neighborhood is best felt on Queen Street. There are around fifteen Tibetan restaurants and a few Tibetan businesses, including a boutique shop, a Tibetan bakery and a hair and beauty salon, on each side of the street. Tibetan restaurants offer typical Tibetan dishes, such as momos, the traditional Tibetan dumplings, thukpas and thenthuks, traditional Tibetan noodle soups (see also McGranahan 2018:369-70 for a description of the Tibetan aspects of Parkdale). The Tibetan presence in Parkdale, although not overwhelming compared with other migrant groups, has become what everyone sees or wants to see, so much so that "the celebrated figure of the immigrant that appeared in the 1990s and 2000s refers nearly exclusively to members of the Tibetan community" (Epstein 2018:718). This, according to Griffin Epstein, is because Tibetans are regarded as a happy and peaceful people that is central to the collective psyche of Parkdale (Epstein 2018:718).

31 When I did my fieldwork, the menus in the Tibetan restaurants, posted in English in the windows or on the front doors, almost disappeared behind the posters of the neighborhood's two main candidates for the 2019 Canadian Federal Elections, i.e. Paul Taylor (New Democratic Party [NDP] candidate) and Arif Virani (Liberal candidate). This tends to show that, however visible, and therefore distinct, Tibetans are in Parkdale, there is a strong connection to local life and politics, which, I would argue, can be accounted for by the Tibetans' successful settlement in the neighborhood. 
Photo 1

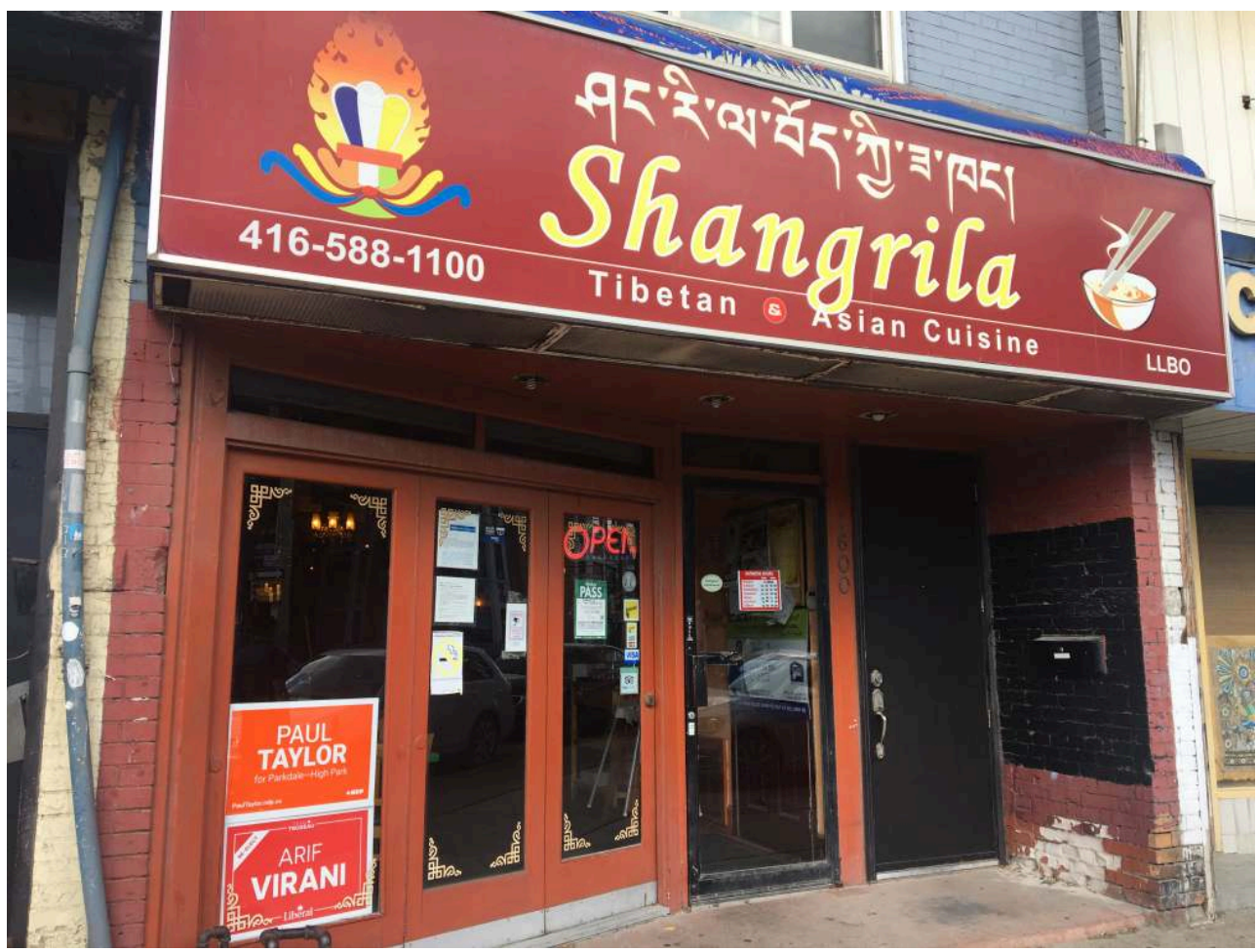

Shangrila, a Tibetan restaurant on Queen Street, Parkdale, at the time of the 2019 Canadian Federal Elections (@ Anne-Sophie Bentz, September 2019)

Parkdale is usually presented as a middle-class neighborhood established at the end of the $19^{\text {th }}$ century that underwent a slow but steady decline, leading to the development of a slum rhetoric in the media in the 1970s (Whitzman 2009; Whitzman and Slater 2006). However, relatively affordable rental housing and good accessibility by public transit to downtown Toronto turned the neighborhood into an attractive area of settlement for newly arrived low-income migrants. This explains why the Tibetans, like the Vietnamese, the Polish and the Hungarians (Roma), chose Parkdale as their place of settlement in Toronto. Chain migration then explains why the next Tibetans to arrive in Toronto also settled down in Parkdale-"as with many newly arrived immigrants, the proximity of co-ethnics was an important factor determining the residential location of this group of Tibetans" (Logan and Murdie 2016:106). This is why Tibetans have a relatively strong association with the neighborhood. In an interview given to Radio Free Asia, Kalsang Dolma recalls: "When we first moved to Canada, we came to Parkdale where it felt very inclusive and homecoming." ${ }^{15}$ Parkdale is indeed regarded as home, that is, a place where Tibetans can develop a sense of community-through networking and socializing with friends, family and the broader Tibetan community (Logan and Murdie 2016). This sense of community is all the more important as, besides the institutional set-up, some authors have added other important explanatory factors that appear to shape migrants' mobilizations, including networks and social capital (Però 2008), which is exactly what Parkdale is about for Tibetans.

з3 However, the neighborhood's gentrification, which started in the 2000s, is slowly but surely affecting the most vulnerable populations, including recently arrived migrants (Epstein 2018; Logan and Murdie 2016; Whitzman 2009; Whitzman and Slater 2006). Low-income housing is still available, pushing Tibetan newcomers to a neighborhood 
which feels like home, but homeownership is next to impossible. Some Tibetans are therefore leaving Parkdale to buy properties in neighboring areas, such as Saint Clair (north of Parkdale) and Etobicoke (west of Parkdale). Etobicoke is indeed where another cluster of Tibetans is now forming. The history of Tibetan settlement there is linked to the building of the Tibetan Canadian Cultural Centre (TCCC) ${ }^{16}$ in 2007. Evidence of the formation of a new "Little Tibet" was already starting to show in the last Canadian census, with 1,475 Tibetans registered in Etobicoke Lakeshore (South Etobicoke) (2016 Canadian Census), and the recent interviews I conducted have largely confirmed this trend.

In Parkdale, and increasingly so in Etobicoke, Tibetans find themselves in a particularly advantageous place to start a process of political integration. If living in Canada affords them legal status, health and social benefits and, most of the time, a job, settling down in one of the two Tibetan neighborhoods in Toronto helps them develop a sense of community. It can be argued that the advantages linked to the host country, in terms of both institutional set-up and local context, explain how Tibetans were able to get politically active. The benefits coming from these two proximate and verticallyembedded fields tend to be mutually reinforcing so as to provide Tibetans with a doubly favorable context.

However, as suggested before, the context should not be limited here to the host country. The role of the Tibetan government-in-exile is essential in inciting Tibetans in Toronto (as elsewhere in the West) to become Tibetan activists. Tibetans are provided with a purpose, becoming "ambassadors" of Tibet, which is all the more noteworthy as the migratory project too is among the factors that appear to shape migrants' mobilizations (Però 2008). What we also see here is an additional field with which Tibetans interact. The context all Tibetans are embedded in therefore consists of three main fields, all of which contribute to positively influencing the Tibetans' political activism in Toronto. If the favorable conditions found in the host country explain how Tibetans were able to mobilize in Toronto, the role played by the Tibetan governmentin-exile may account for the reason why Tibetans decided to become Tibetan activists.

The necessity of a motive reveals the importance of relationality once again: migrants have found in Canada/Toronto a favorable context, but it is still up to the migrants themselves to engage in a multiple player strategic interaction. This refers back to the distinction between players and arenas. If arenas provide stakes, rules and sometimes physical venues, it is ultimately up to the players to make decisions and act. This is what the Strategic Interaction Perspective is all about: arenas are only ever as important as the players who use these arenas to play a strategic game involving other players, all of whom may transform the arenas during the game. Tibetans may have found a favorable context in Canada/Toronto, but the Tibetans' own actions may well have helped make the context even more favorable, thus creating some kind of virtuous circle.

\section{Engaging the Game: The Making of Tibetan Activists}

Tibetans in Toronto are implicated in various non-conventional political activities. They operate branches of international Tibetan organizations (Tibetan Youth Congress [TCY], Tibetan Women Association [TWA] and Students for a Free Tibet [SFT]); they run local organizations (Tibetan Canadian Cultural Centre [TCCC] and Canadian Tibetan 
Association of Ontario [CTAO]); they organize protests and demonstrations; they celebrate key Tibetan dates (Tibetan New Year, Tibetan Independence Day [February 13], Tibetan Uprising Day [March 10], the Dalai Lama's birthday [July 6] and Human Rights Day [December 10]); they organize film and food festivals (Toronto Tibet Film Festival and Eat for Tibet), they engage in hunger strikes (during the protests against the 2008 Beijing Olympics); they initiate campaigns; and they dance in front of the Parkdale Collegiate Institute for Lhakar. ${ }^{17}$ To these non-conventional activities, one can add more conventional forms of political participation, with Tibetans in Toronto becoming members of political parties (New Democratic Party [NDP] and Liberal Party), voting and, lately, running for office (Bhutila Karpoche and Kalsang Dolma). All these initiatives are not just approved, but also supported, and sometimes even initiated by the Tibetan government-in-exile and/or the Dalai Lama.

I will not explain in detail the politicization process that young Tibetans go through to become Tibetan activists (Bentz 2021). Suffice it to recall that the process can be divided into two phases, learning and commitment, which, in the Tibetan case, are influenced not so much by individual families, as by a tightly-knit and highly active community revolving around the Tibetan center in Etobicoke (TCCC). This is where Tibetan children take language, dance and sport classes; this is also where Tibetans of all ages attend political, social and religious events. In fact, all Tibetans in Toronto have a reason to go there, sometimes quite frequently. The role played by political entrepreneurs and organizations has often been regarded as central in migrant, and especially diaspora, mobilization (e.g. Adamson 2012:41; Koinova 2017:600; Sökefeld 2006:269-70). In Toronto, the Tibetan center in Etobicoke (TCCC) ensures that Tibetans get acquainted with social and political mobilization, and this from an early age. Other Tibetan organizations then take over, as Tibetans develop more specific inclinations, e.g. towards youth activism (Tibetan Youth Congress [TYC] and Students for a Free Tibet [SFT]) or women's empowerment (Tibetan Women's Association [TWA]).

As a result, all the non-conventional political activities listed above should not be seen as a set of options to choose from, but as the various activities most Tibetans in Toronto participate in on a regular basis. In fact, it could be argued that becoming a Tibetan activist is not just a possibility given to Tibetans living in Toronto, but almost a necessary outcome. As Kalsang explains: "If you are involved enough in the community, at some point it will come to you, it will be your turn" (Interview with Kalsang). What he could have added is that it is virtually impossible not to get involved. The vast majority of young Tibetans in Toronto have been, or still are, Tibetan activists. The only thing that changes is the degree and length of commitment.

40 I will focus here on the trajectories of two exemplary Tibetans, Bhutila Karpoche and Gelek Badheytsang. What makes them exemplary is that they left their mark, as blogger, activist and politician, on a whole generation of Tibetans living in Canada. However, as explained before, there is a huge pool of young Tibetans who are not only eager to follow their lead, but have already started to do so by becoming Tibetan activists-which is seen as the first step. The emulation process is fully under way and, I would argue, it is only a matter of time before these Tibetans too become exemplary. Sonam, the (at the time of the fieldwork) national director of Students for a Free Tibet (SFT), is one example among many who, a decade later, has embarked on the same path as Bhutila Karpoche and Gelek Badheytsang. 
41 This Tibetan organization, which is open to both Tibetans and non-Tibetans, has an extended network of volunteers $(4,000$ across Canada $)$ who participate in demonstrations and other events, such as action camps, food festivals and concerts. "We are a chapter-based network of young people and activists around the world. Through education, grassroots organizing, and nonviolent direct action, we campaign for Tibetans' fundamental right to political freedom. Our role is to empower and train youth as leaders in the worldwide movement for social justice." ${ }^{18}$ Interestingly, if its first mission is to fight for the cause of Tibet, which here means independence, its second self-assigned mission is to equip young Tibetans (and others) with activist skills.

\section{Photo 2}

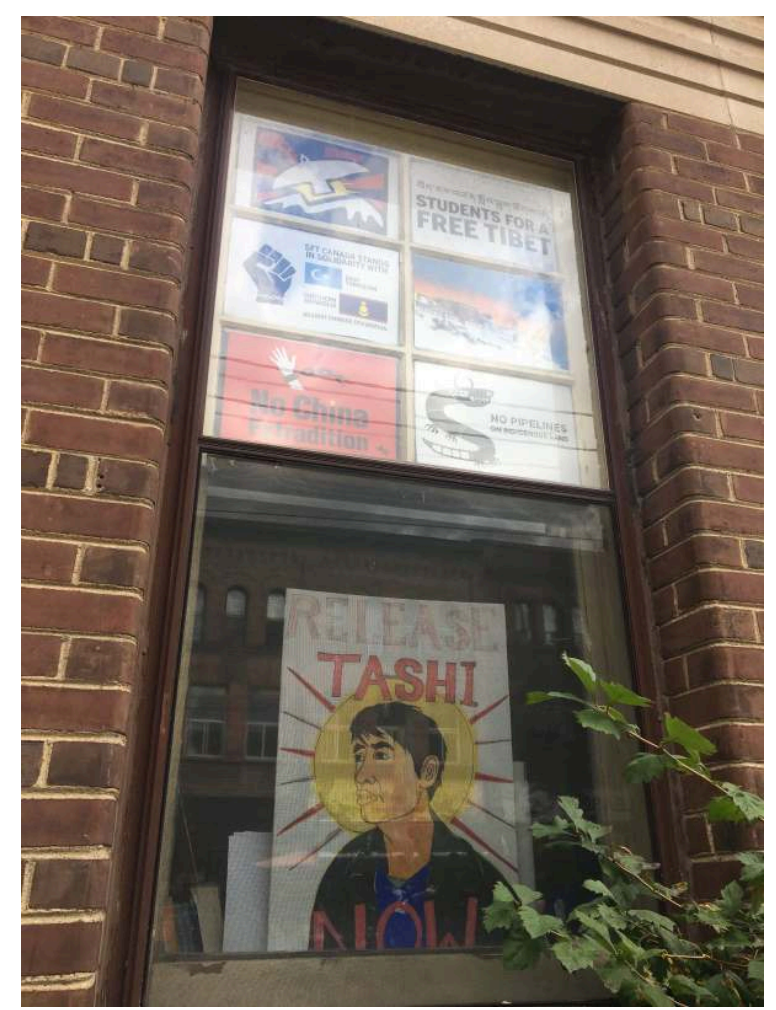

Office of Students for a Free Tibet (SFT) on Queen Street, Parkdale (outside view) (@ Anne-Sophie Bentz, September 2019) 


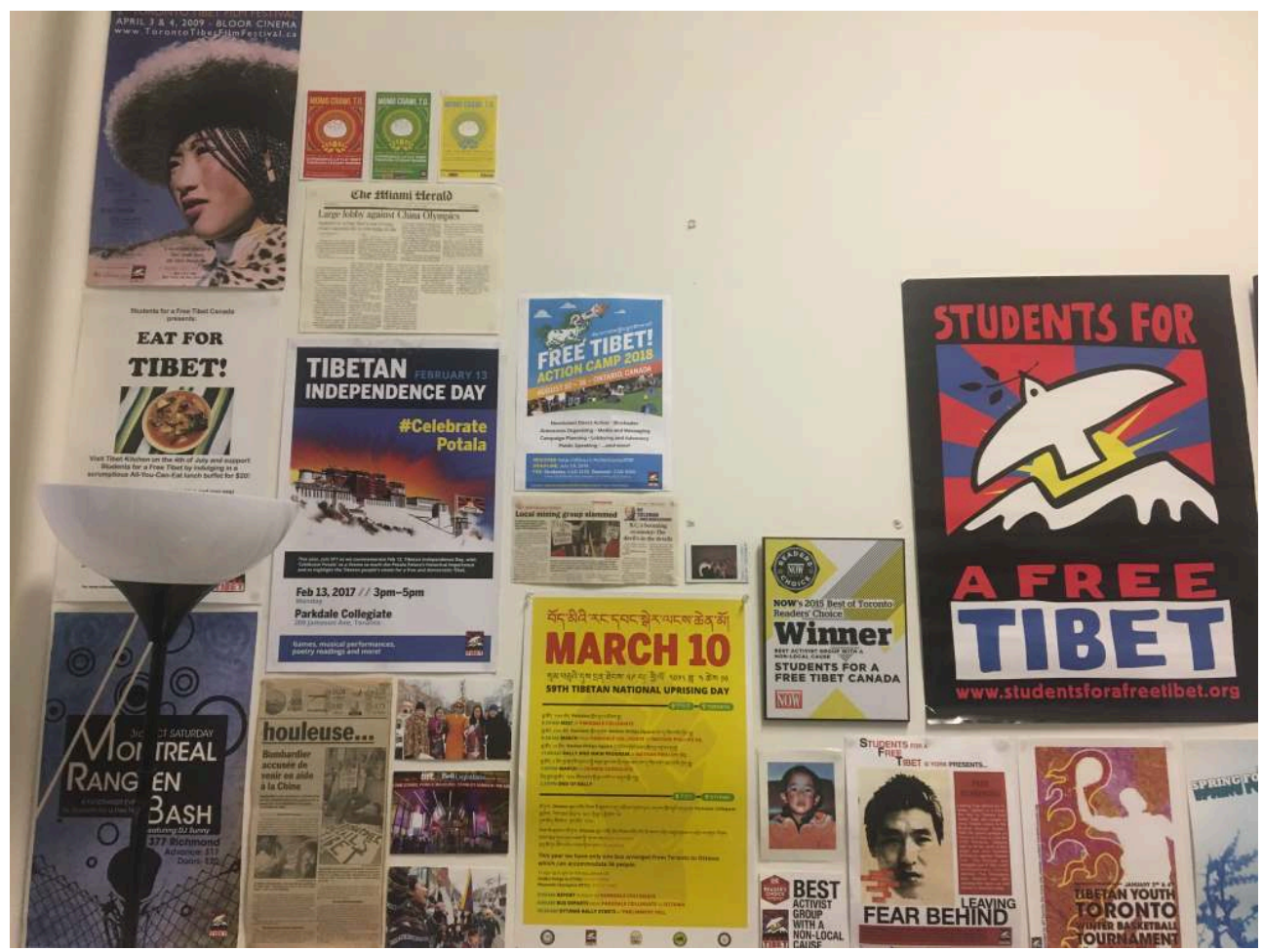

Office of Students for a Free Tibet (SFT) on Queen Street, Parkdale (inside view) (๔ Anne-Sophie Bentz, September 2019)

Gelek Badheytsang remembers: "It was the first and only group I have worked with. That was in 2007 in Vancouver. It was a driver. I was trying to find a community, friends to hang out with. I continued when I came back to Toronto. I followed all kinds of campaigns. At the time it was the 2008 Beijing Olympics" (Interview with Gelek). The first appearances of both Gelek Badheytsang and Bhutila Karpoche in the local media indeed date back to the 2008 Beijing Olympics. They both helped organize the more than 1,000-strong protest that took place in Toronto on March 23, 2008. They were, as spokespersons for Students for a Free Tibet (SFT), quoted at length by the Globe and Mail (Cohen 2008): grabbing an opportunity to put China in the spotlight, they detailed the Tibetans' main demands (calling on the Canadian government to pressure the United Nations to send a fact-finding mission to Tibet and calling on the International Olympic Committee to remove Tibet from the torch relay route). Timing is important here as the 2008 Beijing Olympics have been identified by many of the Tibetans I encountered, and not just in Canada, as a decisive moment for Tibetan mobilization worldwide. While it functioned as an awakening for many young Tibetans, it was, for Bhutila Karpoche and Gelek Badheytsang, the climax of a life as Tibetan activists.

It can be argued that, just like for many other young Tibetans since, ${ }^{19}$ Students for a Free Tibet (SFT) transformed them into prominent Tibetan activists who went on to pursue other Tibetan-related activities. Bhutila Karpoche joined the Tibetan center at Etobicoke (TCCC) as a board member, while Gelek Badheytsang became involved in the Tibetan art community in Toronto and began voicing Tibetan issues by starting a career as a successful blogger. ${ }^{20}$ 

first. This civic phase generally starts with a concern targeted at ethnic/transnational issues and is followed (but not necessarily superseded) by an involvement in local, national and global issues. Another way to look at the transition between the two phases is to consider the various issues of concern as different fields. Tibetan activists start by investing, more or less simultaneously, two proximate and horizontallyoverlapping fields: the Tibetan community in Canada ("immigrant politics") and the cause of Tibet ("homeland politics"). The decision to mobilize around non-Tibetan issues ("political integration") can be regarded as a decision to enter new, and sometimes vertically-embedded, fields on the local, national and global levels. It has been observed that switching to a different arena of decision making means playing another game, for which you may need other capacities and for which you will have different audiences for your words and actions, who may prove more sympathetic or helpful (see Jasper 2006:154 for a discussion on switching arenas). We can wonder how successful Tibetans are in the new arenas. Are they well equipped to play there? To confront new players?

a transition from inward- to outward-looking mobilization has come to the attention of many researchers. They may look at it from different angles, but they all come up with a similar explanatory model that revolves around prior knowledge or experience. An increase in political knowledge, i.e. exposure to political information and social issues, can indeed increase activism (Louis et al. 2016:243-44). In addition, political skills and capital, as well as the mobilizing capacity of transnationally-engaged migrants, are transferable, so that civic activities may be re-oriented towards the host country (Morales and Morariu 2011). It has further been observed that activities prior to civic organizational involvement, such as founding immigrants' organizations, being recruited for initial activities and intensification of organizational involvement, can all explain how migrants become highly active in a new country (Vogel 2008b).

This trajectory, which has been followed by Bhutila Karpoche, Gelek Badheytsang and Kalsang Dolma, along with many other Tibetans, is not only expected, but also encouraged by Tibetan organizations. The second mission of Students for a Free Tibet (SFT), "to empower and train youth as leaders in the worldwide movement for social justice," clearly shows that activism training goes beyond the cause of Tibet. The

South Asia Multidisciplinary Academic Journal, 27 | 2021 
methods used, i.e. education, grassroots organizing, and non-violent direct action, are seen as efficient tools to reach the goal of Tibetan independence, but also as useful activist skills that all young Tibetans should possess. Youth empowerment here means acquiring the mindset of an activist. The Tibetan center in Etobicoke (TCCC) seems to embrace, however unofficially, a similar mission in activism training. "We are a charity, we are not supposed to do politics, but we encourage young people to get interested. Young people join us, they get leadership qualities," explains Tsering (Interview with Tsering).

There is a network of Tibetan organizations in Toronto for Tibetans to choose from. In many cases, this is where they are trained or where they continue to develop their skills as activists, but, as I have shown, such a training is not limited to Tibetan issues. The next question is: where then are these activist skills transferred to?

Issues of interest may depend on individual preference, but, in many cases, there is a link between Tibetan issues and local, national and global issues that are of interest to Tibetan activists. Migrant issues are a case-in-point. Gelek Badheytsang explains: "A lot of things are happening in Parkdale. It is my community, my neighborhood, my city, Canada. I like being active and informed. It is for me a way to contribute back. My people? Tibetans first and foremost. Immigrants and refugees. Racialized communities. ... I am committed to migrants. This is an issue that is of interest to me. It will always be a part of me. I am mindful of discriminations. I support other people, social workers, artists, politicians who are active on these issues." Like him, many Tibetans in Toronto see themselves as migrants, and, as such, are directly concerned by migrant issues. This is especially the case for Tibetans living in Parkdale and Etobicoke, both of which are highly multicultural neighborhoods. Most of their non-Tibetan friends and neighbors are migrants sharing similar concerns and participating in similar activities. This creates a sense of solidarity beyond the Tibetan community.

The interest in migrant issues takes different forms. It can be participation in demonstrations supporting the rights of migrant and/or ethnic communities-in June 2020, Bhutila Karpoche attended the Stop Racism in Swansea march, which was intended as a show of solidarity with Black Lives Matter (BLM) and a demand for justice for Black, Indigenous and People of Color (Lavoie 2020). It can also be support for migrant workers-in April 2016, Gelek Badheytsang wrote an article to defend Tibetan workers who went on strike at the Ontario Food Terminal (Badheytsang 2016) and, in May 2020, Bhutila Karpoche signed a petition urging the federal government to extend COVID-19 financial support to all undocumented migrants in Canada (Keung 2020).

An interest in vulnerable and marginalized populations is also frequent, but this particular concern usually takes a more local form, with Tibetan activists focusing on the situation in Parkdale. Many Tibetans in Toronto either live in or have established a strong connection with a neighborhood that attracted and still attracts many vulnerable and marginal people, including newly arrived low-income migrants, such as Tibetans themselves. To take up but one example: through Students for a Free Tibet (SFT), many Tibetans have supported rent strikes and housing campaigns organized by Parkdale Neighbourhood Land Trust (PNLT) (Interview with Sonam), while Kalsang Dolma and Bhutila Karpoche have both personally joined the local fight for housing rights, by publicly denouncing landlords in Parkdale. ${ }^{22}$

Such sympathy with Parkdale's vulnerable and marginalized people has also prompted some Tibetans to become professionally involved in the neighborhood. Kalsang Dolma 
has worked with Parkdale Community Information Centre (PCIC), whose mission is to help people living in Parkdale, and especially "low-income, vulnerable, disadvantaged, and marginalized populations in Parkdale including newcomers, immigrants, refugees and people with disabilities," “... access community and government resources and services; ... live more independently; and ... participate more fully in community life." ${ }^{23}$ She has also been a long-time board member, as well as director, of Parkdale Community Legal Services (PCLS). ${ }^{24}$ This long-standing and deep commitment to the neighborhood, for which she was awarded the Ontario Newcomer Champion Award by the Province of Ontario in 2014 and the Trailblazer Award at the Women of Diversity Summit and Awards by Afropolitan Canada in 2020, explains why Kalsang Dolma usually presents herself as mainly "a settlement worker and community organizer in Parkdale" (Dolma 2018).

\section{Getting Ready to Play in Local Politics}

54 It is no coincidence that Bhutila Karpoche too presents herself as "a community organizer." ${ }^{25}$ This background can be useful when running for election, especially if the candidate runs a grassroots campaign, which is what Bhutila Karpoche and Kalsang Dolma did. In a somewhat similar situation, Senator Moua and Representative Thao, who came to represent more than 60,000 Hmong Americans in Minneapolis-St. Paul (United States) between 2003 and 2010, had also put forth an activist background-Cy Thao presented himself as a community activist and artist, and Mee Moua, as a lawyer and activist for social change (Hein and Vang 2015). This self-presentation, which may be partly strategic, also shows a strong continuity between the two phases of the migrant's political integration. Experience, which had already proved useful in the transition from inward- to outward-looking mobilization, can also be efficiently transferred when mobilization turns into a more formal mode of political involvement, such as campaigning.

If running for office is the utmost form of political involvement, there are other ways to get involved in local politics that Tibetans in Toronto have explored. Gelek Badheytsang is one such example. His suspicion of political parties has prevented him from seeking public office, but not from supporting his wife [Kalsang Dolma]: "My wife lived in the community of Parkdale. Here are her aspirations and interests. My wife: she has a will to the public office. Me? I find it limiting. To be beholden to certain interests. Sometimes you have to compromise. Being electable. Re-elected" (Interview with Gelek). He became his wife's campaign manager, thus staying in the shadows, while remaining much involved in local politics.

Other Tibetans decided to work for political parties. The National Democratic Party (NDP) started hiring Tibetans in the 2010s. Yudon, a young Tibetan who works for the local city counselor and who was actively involved in Paul Taylor's campaign, recalls: "They hired Tibetans. Bhutila, Tenzin Ngawang. They started there with provincial leaders. After that, whenever there was a campaign, they needed Tibetans" (Interview with Yudon). This was a strategic move in a neighborhood whose Tibetan population had been growing fast, but the need of the political party seemed to have matched a desire on the Tibetans' part to get involved in local political life. I met other young Tibetans who were active in Paul Taylor's campaign. They had helped translate his campaign leaflet into Tibetan and they were distributing the leaflets during a speech he 
made at an event organized by the Tibetan Women's Association (TWA) in front of the Parkdale Collegiate Institute. Paul Taylor, introduced by Bhutila Karpoche, started his speech by reaching to the neighborhood's Tibetan population: "I want to recognize that Tibetans are a critical part of the multicultural fabric that is Canada, that is Toronto, that is Parkdale" (Speech by Paul Taylor on 25 September 2019). If his main objective was to get the Tibetans' votes in the coming elections, his strategy, which meant implicating Tibetans in the campaign, in effect turned the Tibetans' political participation in Canada into something more than just casting a vote.

Photos 4 and 5

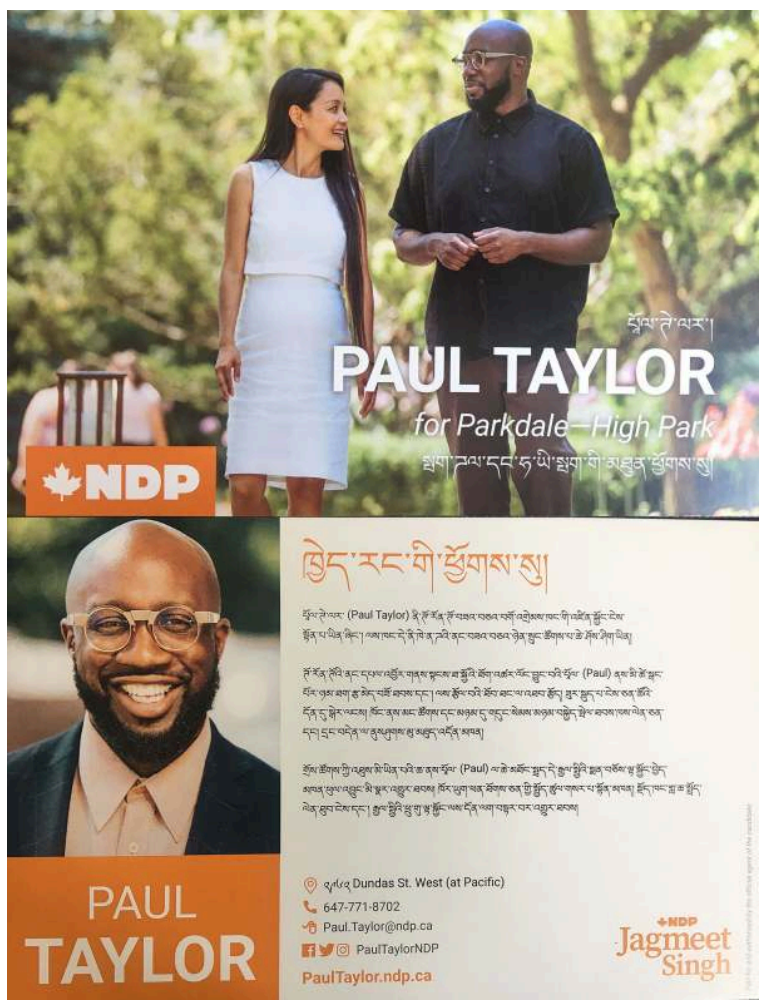

Paul Taylor's campaign leaflet for the 2019 Canadian Federal Elections (@ Anne-Sophie Bentz, September 2019) 


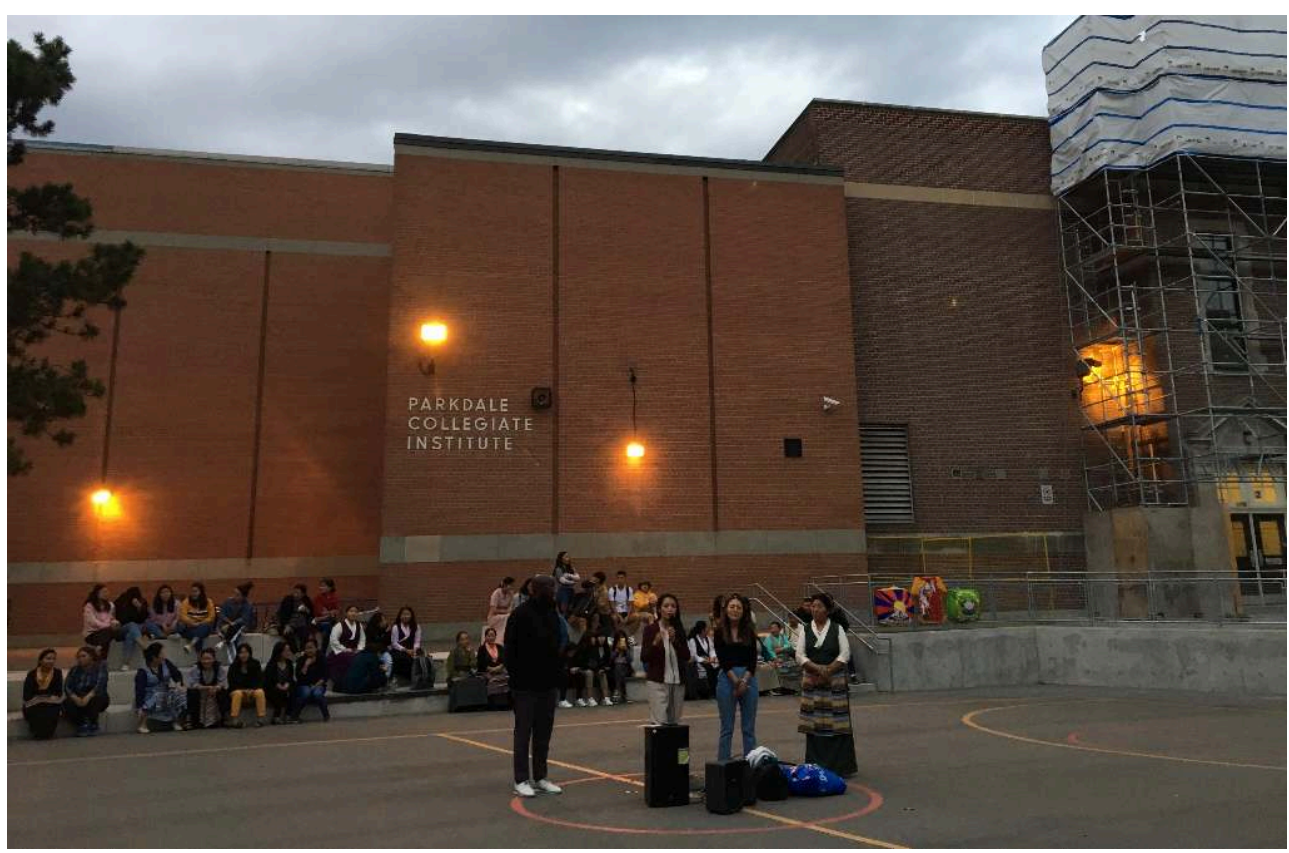

Paul Taylor speaking in front of the Parkdale Collegiate Institute on September 25, 2019. Paul Taylor (on the left) waits while Bhutila Karpoche (holding the microphone) says a few introductory words in Tibetan (@ Anne-Sophie Bentz, September 2019)

A similar argument could be made for involvement in student unions. I heard of and met with some Tibetans who had been active in universities, notably by opening new chapters of Students for a Free Tibet (SFT) (Interviews with Chungtak and Karma), but Chemi Lhamo reached a new level of commitment by becoming president of the University of Toronto's Scarborough campus in February 2019. ${ }^{26}$ It could be argued that involvement with political parties and student unions helped some Tibetans transform, or finalize the transformation, from "active or highly active immigrants" to "active citizens." Their transition, first from inward- to outward-looking mobilization, and then from the civic to the political phase of political integration, appears quite smooth, not least of all because they were already politicized to start with. What is striking is that, by gradually moving to new but proximate fields, they find themselves well equipped to engage these new fields and address new audiences, which helps them to get more confident. This, in turn, explains why Tibetans are not just any players in the new fields. They may have started on the sidelines, but, as these examples show, some of them have recently become the main players in the fields. This is the case for Chemi Lhamo in student unions; this is also the case for Bhutila Karpoche and Kalsang Dolma in local politics.

What also helped these politically active Tibetans was support from the entire Tibetan community. Among Tibetans in Toronto, the recurring sentiments for the two Tibetans who ran for office are pride and admiration. Tsering insists: "I am very proud of them. It is a good example for the young. They did it. It opened the path for them. I am very proud" (Interview with Tsering). Kalsang further admits: "To be involved in politics, you need a certain level of determination. I do admire them for that" (Interview with Kalsang). Most Tibetans also add that it is good for the Tibetan community and/or good for Tibet-"[It is] good, nice, because you are trying to fit into the society where you belong. It brings the Tibetan community in the limelight" (Interview with Anthony). 
Shared pride and admiration may explain why some Tibetans also find Bhutila Karpoche and Kalsang Dolma inspirational, either for themselves or for other young Tibetans. This is the case with Chungtak: "I was helping with Bhutila's campaign. Why? Her being a Tibetan and a woman. And her platform which I liked. I wanted to see a Tibetan up there. The campaign was good" (Interview with Chungtak). Such a perception is the reason why not only Bhutila Karpoche and Kalsang Dolma, but also all the young Tibetans who are groomed to become Tibetan activists, receive support from the entire Tibetan community (Bentz 2021).

of course, this support is particularly important for the two Tibetans who chose the utmost form of political integration, i.e. running for office, and who, subsequently, find themselves at the very end of the political integration process. I propose to look now at the two candidates' campaigns and at the main activities of the one elected politician.

\section{From Campaigns to Elections: Reaching a New High}

60 Kalsang Dolma and Bhutila Karpoche ran two grassroots, but very different campaigns in Parkdale-High Park in 2018. Bhutila Karpoche was endorsed by the National Democratic Party (NDP) to run for the 2018 Ontario General Election. Her involvement with the party had led her to work for former MPP Cheri DiNovo for two mandates. When Cheri DiNovo stepped down, Bhutila Karpoche won the party's nomination for Parkdale-High Park (Tibetan Journal Staff 2017). Her campaign was orchestrated by her party: she was asked to defend Cheri DiNovo's legacy, thus playing the continuity card with a new, young and dynamic face, while simultaneously appealing to Tibetan voters. Kalsang Dolma ran for council in Parkdale-High Park (Ward 4) as an independent candidate during the Toronto Election in 2018. The argument she put forward in her campaign pledge, "the issue of progressive representation," was directed against her main opponent, National Democratic Party (NDP) candidate Gord Perks, who had been a city councilor for twelve years (Dolma 2018). If she chose to play the change-fordiversity card, it was arguably because this was the only card available to her in a race where she did not stand much chance (DiMatteo 2018). These are two different experiences of local Canadian politics. If the experience was cut short for Kalsang Dolma, Bhutila Karpoche won by a comfortable majority.

61 These two different outcomes can be analyzed through a Strategic Interaction Perspective by focusing on the interactions of the two candidates in the field of local politics. Fields are governed by rules, which can be either formal or informal, explicit or implicit, advantage some players and disadvantage others, depending, among other things, on resources, skills, status and position (Fligstein and MacAdam 2012; Jasper and Duyvendak 2015). Bhutila Karpoche and Kalsang Dolma knew the rules of the field. To take but one example, both of them knew how important it was to get endorsed by one of the major Canadian parties, which is why both of them sought that endorsement. Whereas Bhutila Karpoche was endorsed by the National Democratic Party (NDP), Kalsang Dolma unsuccessfully tried to run for the Liberal Party (for the 2018 Ontario General Election). It is because she could not that, instead, she ran for council as an independent candidate during the Toronto Election in 2018-an election for which candidates do not need to be backed up by a political party (Interview with Yudon). However, failure to get a party's endorsement put her at a disadvantage that 
was made worse by her opponent Gord Perk's support of the National Democratic Party (NDP).

The two candidates, who clearly did not have the same resources, did not hold the same status within the field either. Following the distinction in players as incumbents or challengers (Fligstein and McAdam 2012), it could be argued that Bhutila Karpoche was an incumbent, while Kalsang Dolma was only a challenger. Bhutila Karpoche was already involved in the local political field. As a member of MPP Cheri DiNovo's team, not only did she have time to develop astute political skills, she was also a part of a collective player that could wield some influence, which is what incumbents do. Kalsang Dolma, even though she had already lent her support to the Liberal Party in the past, was newer to the political game. She was the challenger in both meanings of the word: as a player, waiting on the sidelines to enter a new field, and as a candidate, competing against incumbent candidate (and player) Gord Perks.

Once elected, Bhutila Karpoche had to find the best way, both as an individual and as a team member of a collective player, to invest the political scene of Toronto. Her official homepage states that she is "active on issues around social justice and public health" and that she is "a longtime advocate of affordable housing, workers' rights, and public healthcare." ${ }^{27}$ This short self-presentation encapsulates the issues of interest to her, most of which she has supported, in one way or another, since her election in June $2018 .^{28}$

Photo 7

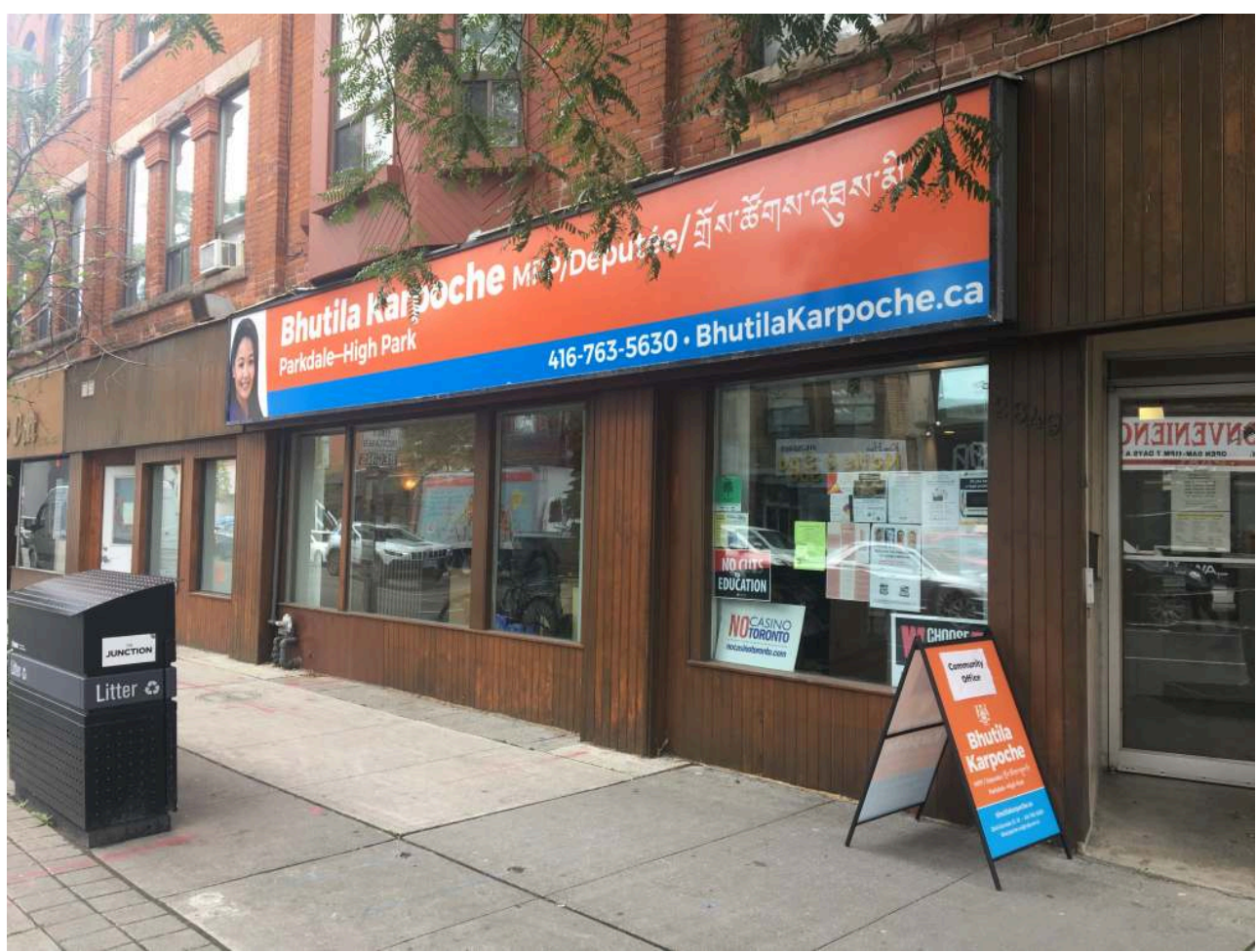

Bhutila Karpoche's office in Parkdale (๔ Anne-Sophie Bentz, October 2019)

I have already provided examples of her defense of workers' and housing rights, as well as her engagement for migrants and against racism. Another important issue to her is public health. This has to do at least partly with her academic background-she holds a 
Master of Public Health from the University of Toronto and is a PhD candidate in Public Health Policy at Ryerson University. She has been a public health researcher focusing on the social determinants of health. It was in that capacity that she co-wrote a report, “'Working So Hard, Still So Poor!' A Public Health Crisis in the Making: The Health Impacts of Precarious Work on Racialized Refugee and Immigrant Women," that is still praised as a landmark in the study of public health in Toronto. While her training may explain her interest in health issues, her knowledge has also been put to good use by her party. Bhutila Karpoche's official title is deputy opposition whip and mental health and addictions critic. She has embraced her role by lending her support to a large number of health issues since she has been elected. These include drug addictions (Jeffords 2019b; Karpoche 2018), maternal mental health (Tibetan Journal Staff 2019), child and youth mental health (Jeffords 2020) and problem gambling (Jeffords 2019a).

Bhutila Karpoche also heartedly supports women's empowerment. Asked by Toronto Star to comment on Canada's 1929 promise [about women's participation in politics], she stressed the need to do better still in electing women from diverse communities that reflect the population (Moon et al. 2019). This interest in women's empowerment dates back to the time when she was working for MPP Cheri DiNovo. She was then engaged in a program designed to boost girls' interest in politics, which she was very enthusiastic about: "It's just so good to see. ... Even if they don't pursue political office, they are still plugged in and active in so many ways." The Girls Government Program is still ongoing and Bhutila Karpoche has not stopped playing an active role with local girls at the Parkdale Public School (Rushowy 2019).

These are all issues she got involved with as community organizer, but, since then, two things have changed. The first is a disproportionate emphasis on health problems, which has to do with a genuine interest in health issues, as well as a strategic use of her training by her party. The second is the means available to her to put these issues forward. As elected politician, her voice has become more powerful. When she sends letters to local newspapers, these letters get published; when she joins a demonstration, she is the one who will be asked to comment; when she publicly calls on others to act, her call will be relayed by local newspapers; when she makes a speech in parliament, the video of the speech goes viral on social media. She also has access to more formal means, such as private member's bills, which she has used so far on postpartum mental health, menstrual hygiene and wait time for children dealing with mental health issues. It could be argued that Bhutila Karpoche has been very successful in effectively publicizing all these issues. She has even made a name for herself by tackling some of them in a new and energetic manner-e.g. she delivered her speech on maternal mental health while carrying and cuddling her own baby (Tibetan Journal Staff 2019). All in all, it seems that Bhutila Karpoche's position as incumbent in the field of local party politics has borne fruit.

67 It is tempting to see her as a perfect example of successful political integration-a Tibetan activist, who becomes a community organizer in Parkdale, then works for the National Democratic Party (NDP) and finally gets elected as member of the Ontario Provincial Parliament. However, it remains debatable what the end-stage of the process of political integration really entails. The example of Senator Moua and Representative Thao has shown that politicians with an ethnic background are expected to rally on campaigns to defend specifically ethnic causes (Hein and Vang 2015). 

cause. The first time was when, dressed in the traditional Tibetan dress, she made a powerful speech in parliament on World Human Rights on the commemoration of the $30^{\text {th }}$ anniversary of the Dalai Lama's reception of the Nobel Peace Prize (Tibetan Journal Staff 2019). The second time was when she tabled a bill to mark July of each year as Tibetan Heritage month in Ontario. Bill 131, which "aims to recognize the important contributions made by Tibetan-Canadians in Ontario, as well as bring awareness to Tibetan issues," passed unanimously on September 24, 2020. ${ }^{29}$ These symbolic achievements, which amply circulated in Tibetan media, ${ }^{30}$ are highly appreciated by the Tibetan government-in-exile, as can be seen from the reaction after Bill 131 was passed: "Tibetans and Tibet supporters have found a reason to rejoice with a new milestone in the growing momentum of support for the Tibetan cause."31

as if Bhutila Karpoche were fulfilling two roles at the same time, the role of a politically integrated Tibetan-Canadian, as well as the role of "ambassador" of Tibet. This enables us to pursue some of the theoretical discussions about the migrant's dual loyalties. It has been acknowledged both that the home country has an impact on the migrant's political integration in the host country (Gabrielli et al. 2017; ØstergaardNielsen 2003) and that the home country's impact can be positive (Morales and Morariu 2011; Portes et al. 2008). The example of Bhutila Karpoche further shows that such an impact can occur at every stage, even at the very end stage of the migrant's political integration process, while remaining positive throughout.

Bhutila Karpoche's is a case where, in James Jasper's view, players overlap with each other. This is often the case, but it is no coincidence that the example taken to illustrate that point should be the elected politician: "An MP is also a member of her party, occasionally pursuing its goals (fundraising, for instance) alongside legislative ones, and she may also be a member of a protest group seeking social change or justice" (Jasper and Duyvendak 2015:11). This theoretical example fits Bhutila Karpoche's profile quite well. She has both party and legislative duties, as a member of, respectively, the New Democratic Party (NDP) and the Ontario Provincial Parliament; she also keeps branding herself as an apostle of social change and public health, which takes her back to the time when she was a community organizer; last but not least, her most recent moves show that she has never ceased to be the "ambassador" of Tibet the Tibetan government-in-exile wanted her to be. This raises the question of the migrant's dual loyalties, which I have already briefly addressed, but also the question of overall efficiency. Bhutila Karpoche has, over the years, added up new arenas, and therefore also new players and audiences, to play a strategic interaction game on several different levels, both as individual player and as part of a collective player. How can she possibly hope to win in all these different arenas? Her current popularity indicates that she has done a pretty good job: 1) at satisfying her different audiences, such as Tibetans in Toronto, her constituency in Parkdale, the worldwide Tibetan community, her fellow members of the New Democratic Party (NDP) and the citizens of Toronto; 2) at adapting the resources at her disposal, notably by using the new means available to her as elected politician (such as private member's bills); 3) at reaching some of her stated goals by advancing her various causes of concern, both Tibetan (awareness of the Tibetan cause and defense of Tibetan migrants in Canada) and non-Tibetan (particularly, workers' and housing rights, migrant issues, public health and women's empowerment)-in this regard, it must be noted that it is easier to do so as an elected 
politician in the opposition, as what is expected of her is to publicize, rather than to solve, these issues.

71 I would argue that Bhutila Karpoche's success is due to the overall compatibility, and therefore also relevance, of the various arenas, which in turn implies that the different audiences, as well as the goals, which are sometimes targeted at different audiences and players in different arenas, are also fairly compatible.

\section{Conclusion: What it Means to Accept the Rules of the Political Game}

72 I have shown in this article that, just like Bhutila Karpoche, Kalsang Dolma and Gelek Badheytsang, the Tibetans who chose to enter into local politics in Toronto, either directly or indirectly, were already politicized to start with. I have explained that this has to do mainly with the thorough process of politicization many Tibetans underwent in the Tibetan organizations present in Toronto (Bentz 2021). They are the "ambassadors" of Tibet the Tibetan government-in-exile wanted them to be, and yet, because of that, they have also simultaneously turned into concerned citizens of Canada.

This is also to say that the Tibetans of Toronto are embedded in various arenas. James Jasper uses the war metaphor to explain the relations between the different arenas, comparing the strategic interactions waged simultaneously in different arenas with a number of fronts adding up to a war (Jasper 2006:144). I would like to argue, on the basis of this fieldwork, that Tibetans are confronted with an increasing number of fronts in Toronto when becoming, not successively (as first thought), but simultaneously "active or highly active immigrants" and "active citizens." While many (especially young) Tibetans engage in transnational and local Tibetan activism (what I called an inward-looking type of mobilization), before tackling local, national and global issues (what I referred to as an outward-looking type of mobilization), I have shown that for a few, but fast-growing number of Tibetans, involvement in another arena, the political scene of Toronto, is now also considered.

This engagement in an increasing number of arenas tends to increase the complexity of the game, not least of all because the number of arenas is linked to the number of audiences, which players need to balance one way or another, thereby facing many different dilemmas (Jasper 2006). Just as a war is difficult to wage on several fronts, a game is more difficult to play in different arenas comprising different audiences, each one of which deserves specific strategies. The examples of Kalsang Dolma and Bhutila Karpoche, but also of Senator Moua and Representative Thao (Hein and Vang 2015) tend to show that, in some cases, it is unlikely that players will completely let go of previous arenas of engagement, which is sometimes done so as to better adapt the game to the new arena and the new audience. I would like to suggest that this is particularly the case for players who share a strong ethnic identity which lies at the core of the first arenas of engagement-both Hmong and Tibetans are fighting for an endangered homeland.

What is especially interesting in our case is that the new arena of engagement, local politics in Toronto, is an entirely new arena, which cannot be said to be vertically embedded in the other arenas Tibetans in Toronto had become used to engage in. The 
question was: were our key players ready to step up the game? I would argue that they all were in their own way. Gelek Badheytsang turned out to be an efficient campaign manager. His knowledge of the local media clearly helped publicize Kalsang Dolma's campaign-her campaign, though not backed by any political party, was more visible than Bhutila Karpoche's. Kalsang Dolma was, and still is, very popular as a social worker in Parkdale. She knew her prospective constituency extremely well. She did not win the elections, but she showed other Tibetans, and possibly other migrants in Parkdale, a way forward. Bhutila Karpoche had learnt the ropes of the game as a longtime member of MPP Cheri DiNovo's team. Not only did she win the elections, but she made a name for herself as an elected politician in the following months-this shows that she was ready to become a key player in this new arena.

While these three key players were ready to step up the game, we must recall that there are many more Tibetans in Toronto getting ready to follow in their footsteps. But these bystanders, who "if nothing else, ... actively interpret each other's words and actions, waiting to do more if necessary" (Jasper 2006:122), are not just any bystanders: as we have seen, they went through a thorough politicization process in the Tibetan community of Toronto which equipped them as Tibetan activists, but also as activists likely to invest other, often proximate, fields. This being said, it should not be forgotten that, while some Tibetans are ready to accept the rules of the political game, in order to build a career as politicians, thereby opting for the utmost form of political integration, other Tibetans who are also on the path of political integration may refuse the compromises associated with the political game in order to retain a stronger measure of freedom to continue influencing the game from the margins.

\section{BIBLIOGRAPHY}

Adamson, Fiona. 2012. "Constructing the Diaspora: Diaspora Identity Politics and Transnational Social Movements." Pp. 25-42 in Politics from Afar: Transnational Diasporas and Networks, edited by T. Lyons and P. Mandaville. New York: Columbia University Press.

Anderson, Benedict. 1998. "Long-Distance Nationalism." Pp. 58-74 in The Spectre of Comparisons: Nationalism, Southeast Asia and the World, edited by B. Anderson. London: Verso.

Bentz, Anne-Sophie. 2010. Les Réfugiés tibétains en Inde. Nationalisme et exil. Paris: Presses Universitaires de France.

Bentz, Anne-Sophie. 2022. "Tibetan Mobilisation in Canada: How Do Young Tibetans in Toronto Become Politically Active?" DESI:79-113.

Badheytsang, Gelek. 2016. "Tibetan Immigrants Fight for Fair Wages and Dignity at the Ontario Food Terminal." NOW, May 2. Retrieved July 26, 2021 (https://nowtoronto.com/news/tibetanimmigrants-fight-for-fair-wages-and-dignity-at-the-ontario-food-terminal/).

Badheytsang, Gelek. 2019. “Admiring \& Admonishing the Dalai Lama.” Lion's Roar, July 5. Retrieved July 26, 2021 (https://www.lionsroar.com/commentary-admiring-admonishing-thedalai-lama/). 
Batarseh, Robert C. 2016. "Inside/Outside the Circle: From the Indochinese Designated Class to Contemporary Group Processing.” Refuge 32(2):54-66.

Bradley, Andrea. 2010. "Beyond Borders: Cosmopolitanism and Family Reunification for Refugees in Canada." International Journal of Refugee Law 22(3):379-403.

Brubaker, Roger. 2010. "Migration, Membership, and the Modern Nation-State: Internal and External Dimensions of the Politics of Belonging." Journal of Interdisciplinary History 41(1):61-78.

CBC Staff. 2019. “'China is your Daddy': Backlash against Tibetan Student's Election Prompts Questions about Foreign Influence.” CBC, February 14. Retrieved July 26, 2021 (https:// www.cbc.ca/news/canada/toronto/china-tibet-student-election-1.5019648).

CBC Staff. 2019. "China Denies Role in Backlash against Tibetan Student's Election at U of T." CBC, February 15. Retrieved July 26, 2021 (https://www.cbc.ca/news/canada/toronto/china-deniesrole-in-backlash-against-tibetan-student-s-election-at-u-of-t-1.5021226).

Citizenship and Immigration Canada. 2012. "Temporary Public Policy Concerning Tibetans Living in the State of Arunachal Pradesh in India." Government of Canada. Retrieved July 26, 2021 (http://www.cic.gc.ca/english/department/laws-policy/tibet.asp).

Cohen, Tobi. 2008. “Tibet Supporters Take to Streets of Toronto.” Globe and Mail, March 24. Retrieved July 26, 2021 (https://www.theglobeandmail.com/news/national/tibet-supporterstake-to-streets-of-toronto/article18447258/).

Contenta, Sandro. 2010. "For Tibetan Refugees, Canada was Literally the New World." Toronto Star, October 23. Retrieved July 26, 2021 (https://www.thestar.com/news/world/2010/10/23/ for_tibetan_refugees_canada_was_literally_the_new_world.html).

DiMatteo, Enzo. 2018. “Toronto Election 2018: A Voter's Guide to the Good, Bad, Ugly and Progressive Choices for Council.” NOW, October 17. Retrieved July 26, 2021 (https:// nowtoronto.com/news/toronto-election-2018-voters-guide).

Dolma, Kalsang. 2018. “Toronto Election 2018: The Inconvenient Truth is That Our Progressive Politics is Mostly White.” NOW, October 22. Retrieved July 26, 2021 (https://nowtoronto.com/ news/toronto-election-2018-politics-racism).

Dorjee, Tenzin. 2013. "Why Lhakar Matters: The Elements of Tibetan Freedom." Tibetan Political Review, January 10. Retrieved July 26, 2021 (https://sites.google.com/site/tibetanpoliticalreview/ articles/whylhakarmatterstheelementsoftibetanfreedom).

Epstein, Griffin. 2017. “A Kinder, Gentler Gentrification: Racial Identity, Social Mix and Multiculturalism in Toronto's Parkdale Neighborhood.” Social Identities 24(6):707-26.

Fligstein, Neil and Doug McAdam. 2011. "Toward a General Theory of Strategic Action Fields." Sociological Theory 29(1):1-26.

Fligstein, Neil and Doug McAdam. 2012. A Theory of Fields. Oxford: Oxford University Press.

Gabrielli, Lorenzo, Sonia Gsir, and Ricard Zapata-Barrero. 2017. "Political and Civic Participation of Immigrants in Host Countries: An Interpretative Framework from the Perspective of the Origin Countries and Societies." Pp. 87-116 in Migrant Integration between Homeland and Host Society, edited by A. Weinar, A. Unterreiner, and P. Fargues. Berlin: Springer.

Garbaye, Romain. 2005. Getting into Local Power: The Politics of Ethnic Minorities in British and French Cities. Oxford: Blackwell.

Goodwin, Jeff and James M. Jasper, eds. 2012. Contention in Context: Political Opportunities and the Emergence of Protest. Stanford: Stanford University Press. 
Gropas, Ruby. 2008. "Is Naturalisation a Factor in Immigrant Activism?” Pp. 145-60 in Highly Active Immigrants - A Resource of European Civil Societies, edited by D. Vogel. Frankfurt: Peter Lang.

Hein, Jeremy and Nengher Vang. 2015. "Politicians and Social Movements: The Impact of Electoral Victory on Local, National, and Transnational Activism by Hmong Americans in Minneapolis-St. Paul." Social Movement Studies 14(2):164-79.

Hess, Julia Meredith. 2006. "Statelessness and the State: Tibetans, Citizenship, and Nationalist Activism in a Transnational World." International Migration 44(1):79-103.

Hess, Julia Meredith. 2009. Immigrant Ambassadors: Citizenship and Belonging in the Tibetan Diaspora. Stanford: Stanford University Press.

Itzigsohn, José. 2000. "Immigration and the Boundaries of Citizenship: The Institutions of Immigrants’ Political Transnationalism.” International Migration Review 34(4):1126-54.

Jasper, James M. 2006. Getting Your Way: Strategic Dilemmas in the Real World. Chicago: Chicago University Press.

Jasper, James M. 2012. "Introduction: From Political Opportunity Structures to Strategic Interaction." Pp. 1-33 in Contention in Context: Political Opportunities and the Emergence of Protest, edited by J. Goodwin and J.M. Jasper. Stanford: Stanford University Press.

Jasper, James M. and Jan Willem Duyvendak, eds. 2015. Players and Arenas: The Interactive Dynamics of Protest. Amsterdam: Amsterdam University Press.

Jeffords, Shawn. 2019a. "Ontario Eliminates Funding to Group that Researches Problem Gambling.” Toronto Star, May 5. Retrieved July 26, 2021 (https://www.thestar.com/politics/ provincial/2019/05/04/ontario-eliminates-funding-to-group-that-researches-problemgambling.html).

Jeffords, Shawn. 2019b. "Provincial Data Shows 435 Opioid Overdose Deaths to Start 2019, up from 307." Toronto Star, December 13. Retrieved July 26, 2021 (https://www.thestar.com/news/ ontario/2019/12/13/provincial-data-shows-435-opioid-overdose-deaths-to-start-2019-upfrom-307.html).

Jeffords, Shawn. 2020. "Child and Youth Mental Health Service Wait Lists in Ontario Double to 28,000, Report Says.” Toronto Star, January 27. Retrieved July 26, 2021 (https://www.thestar.com/ politics/provincial/2020/01/27/child-and-youth-mental-health-service-wait-lists-doubleto-28000-report-says.html).

Karpoche, Bhutila. 2018. “Readers' Letters: Users Dying as Decision Delayed.” Toronto Star, October 6. Retrieved July 26, 2021 (https://www.thestar.com/opinion/letters_to_the_editors/ 2018/10/06/users-dying-as-decision-delayed.html).

Kennedy, Brendan. 2018. “NDP’s Bhutila Karpoche Wins Parkdale-High Park, Becoming First Tibetan Ever Elected to Public Office in North America." Toronto Star, June 7. Retrieved July 26, 2021 (https://www.thestar.com/news/queenspark/2018/06/07/karpoche-makes-history-withndp-win-becoming-the-first-tibetan-ever-elected-to-public-office-in-north-america.html).

Keung, Nicholas. 2020. "Politicians from Coast to Coast Urge COVID-19 Help for Undocumented Workers.” Toronto Star, May 4. Retrieved July 26, 2021 (https://www.thestar.com/news/canada/ 2020/05/04/my-biggest-fear-is-that-we-are-going-to-end-up-on-the-street-letter-urgescovid-19-help-for-undocumented-workers.html).

Koinova, Maria. 2017. "Beyond Statist Paradigms: Sociospatial Positionality and Diaspora Mobilization in International Relations.” International Studies Review 19(4):597-621. 
Lavoie, Joanna. 2020. "West Toronto Residents Rally and March against Racism." Toronto Star, June 27. Retrieved July 26, 2021 (https://www.thestar.com/news/gta/2020/06/27/west-torontoresidents-rally-and-march-against-racism.html).

Lhamo, Choekyi. 2020. “Ontario Passes Bill to Mark “Tibetan Heritage Month.” Phayul, September 28. Retrieved July 26, 2021 (http://www.phayul.com/2020/09/28/44505/).

Logan, Jennifer J. 2010. “'There's No Place Like Home': A Snapshot of the Settlement Experiences of Newcomer Tibetan Women in Parkdale, Toronto.” PhD dissertation, Geography Department, Toronto York University. ProQuest Dissertations Publishing.

Logan Jennifer J., and Robert Murdie. 2016. "Home in Canada? The Settlement Experiences of Tibetans in Parkdale, Toronto." Journal of International Migration and Integration 17(1):95-113.

Loriggio, Paula. 2008. “'At Home' in Little Tibet.” Toronto Star, May 15. Retrieved July 26, 2021 (https://www.thestar.com/news/gta/2008/05/15/at_home_in_little_tibet.html).

Louis, Winnifred, Catherine Amiot, Emma Thomas, and Leda Blackwood. 2016. "The 'Activist Identity' and Activism Across Domains: A Multiple Identities Analysis.” Journal of Social Issues 72(2):242-63.

MacPherson, Seonaigh, Anne-Sophie Bentz, and Dawa Bhuti Ghoso. 2008. "Global Nomads: The Emergence of the Tibetan Diaspora (Part I)." Migration Policy Institute. Retrieved July 26, 2021 (https://www.migrationpolicy.org/article/global-nomads-emergence-tibetan-diaspora-part-i).

Marshall, Thomas Humphrey. 1964. Class, Citizenship, and Social Development. Garden City, NY: Doubleday.

McAdam, Doug, Sidney G. Tarrow, and Charles Tilly. 2001. Dynamics of Contention. Cambridge: Cambridge University Press.

McConnell, Fiona. 2016. Rehearsing the State: The Political Practices of the Tibetan Government-in-Exile. Oxford: Wiley-Blackwell.

McGranahan, Carole. 2018. "Refusal as Political Practice: Citizenship, Sovereignty, and Tibetan Refugee Status.” American Ethnologist 45(3):367-79.

McGranahan, Carole. 2010. Arrested Histories: Tibet, the CIA, and Memories of a Forgotten War. Durham, NC: Duke University Press.

McKown, Colleen. 2011. "Canada to Welcome 1000 Tibetan Refugees from India." Tibet Post International, July 20. Retrieved July 26, 2021 (http://www.thetibetpost.com/en/news/ international/1887-canada-to-welcome-1000-tibetan-refugees-from-india).

Moon, Jenna, Priya Ramanujam, Evelyn Kwong, Wanyee Li, Ayesha Nasir, and Andrea Macdonald. 2019. "Still Pushing for Personhood: 90 Years after Canada Recognized the Rights of (Some) Women, What the Fight Looks Like Now." Toronto Star, October 18. Retrieved July 26, 2021 (https://www.thestar.com/news/canada/2019/10/18/still-pushing-for-personhood-90-yearsafter-canada-recognized-the-rights-of-some-women-what-the-fight-looks-like-now.html).

Morales, Laura and Miruna Morariu. 2011. 'Is 'Home' a Distraction? The Role of Migrants' Transnational Practices in their Political Integration into Receiving-Country Politics." Pp. 140-71 in Social Capital, Political Participation and Migration in Europe: Marking Multicultural Democracy Work?, edited by L. Morales and M. Giugni. London: Palgrave Macmillan.

Ngabo, Gilbert. 2019. “A West-End Landlord Says his Building is a Tourist Property. Tenants Being Evicted and the City Disagree.” Toronto Star, October 3. Retrieved July 26, 2021 (https:// 
www.thestar.com/news/gta/2019/10/03/a-west-end-landlord-says-his-building-is-a-touristproperty-tenants-being-evicted-and-the-city-disagree.html).

Østergaard-Nielsen, Eva, ed. 2003. International Migration and Sending Countries Perceptions, Policies and Transnational Relations. Basingstoke: Palgrave Macmillan.

Planning Commission. 2010. Demographic Survey of Tibetans in Exile-2009. Dharamsala, India: Central Tibetan Administration.

Portes, Alejandro. 1999. "Conclusion: Towards a New World - The Origins and Effects of Transnational Activities." Ethnic and Racial Studies 22(2):463-77.

Portes, Alejandro, Cristina Escobar, and Renelinda Arana. 2008. "Bridging the Gap: Transnational and Ethnic Organizations in the Political Incorporation of Immigrants in the United States." Ethnic and Racial Studies 31(6):1056-90.

Raska, Jan. 2013. “Tibetan Immigration to Canada." Canadian Museum of Immigration at Pier 21. Retrieved July 26, 2021 (https://www.pier21.ca/blog/jan-raska/tibetan-immigration-to-canada).

Raska, Jan. 2016. "Humanitarian Gesture: Canada and the Tibetan Resettlement Program, 1971-

5." Canadian Historical Review 97(4):546-75.

Rushowy, Kristin. 2019. “Girls Government Program Gives Young Women Glimpse into Political Life.” Toronto Star, August 5. Retrieved July 26, 2021 (https://www.thestar.com/politics/ provincial/2019/08/04/girls-government-program-gives-young-women-glimpse-into-politicallife.html).

Sökefeld, Martin. 2006. "Mobilizing in Transnational Space: A Social Movement Approach to the Formation of Diaspora." Global Networks 6(3):265-84.

Tibetan Journal Staff. 2017. "Tibetan Origin Canadian Elected as 2018 MP Candidate." Tibetan Journal, September 15. Retrieved July 26, 2021 (https://www.tibetanjournal.com/tibetan-origincanadian-elected-2018-mp-candidate/).

Tibetan Journal Staff. 2018. "First Tibetan, Bhutila Karpoche Wins Election in Canada." Tibetan Journal, June 8. Retrieved July 26, 2021 (http://www.tibetanjournal.com/first-tibetan-bhutilakarpoche-wins-election-canada/).

Tibetan Journal Staff. 2019. “Tibetan Origin Canadian MP Going Viral with Powerful Speech.” Tibetan Journal, December 24. Retrieved July 26, 2021 (https://www.tibetanjournal.com/tibetanorigin-canadian-mp-going-viral-with-powerful-speech/).

Tibetan Review Staff. 2020. "Canadian Province Declares July as 'Tibetan Heritage Month.” Tibetan Review, September 25. Retrieved July 26, 2021 (https://www.tibetanreview.net/canadianprovince-declares-july-as-tibetan-heritage-month/).

Vertovec, Steven. 2003. "Migration and Other Modes of Transnationalism: Towards Conceptual Cross-Fertilization.” International Migration Review 37(3):951-73.

Vogel, Dita, ed. 2008a. Highly Active Immigrants - A Resource of European Civil Societies. Frankfurt: Peter Lang.

Vogel, Dita. 2008b. "Becoming Active in a New Country: In Search of Favourable Activation Conditions." Pp. 109-28 in Highly Active Immigrants - A Resource of European Civil Societies, edited by D. Vogel. Frankfurt: Peter Lang.

Whitzman, Carolyn and Tom Slater. 2006. "Village Ghetto Land: Myth, Social Conditions, and Housing Policy in Parkdale, Toronto, 1879-2000.” Urban Affairs Review 41(5):673-96. 
Whitzman, Carolyn. 2009. Suburb, Slum, Urban Village: Transformations in Toronto's Parkdale Neighbourhood, 1875-2002. Vancouver: UBC Press.

Zapata-Barrero, Ricard and Ruby Gropas. 2012. "Active Immigrants in Multicultural Contexts: Democratic Challenges in Europe.” Pp. 167-91 in European Multiculturalism: Cultural, Religious and Ethnic Challenges, edited by A. Triandafyllidou, T. Mododd, and N. Meer. Edinburgh: Edinburgh University Press.

\section{NOTES}

1. See https://www.bhutilakarpoche.ca/. All links provided in this article were valid as of January 2021.

2. I use "Tibetans" to refer to the varied group of people living in Canada 1) who have a link to Tibet which is officially referred to as a common ethnic origin (2016 Canadian Census) and 2) who, because of this link, have developed a sense of belonging to the Tibetan community.

3. This nickname appears in local newspapers (e.g. Loriggio 2008) and blogs (e.g. https:// www.blogto.com/city/2018/08/little-tibet-parkdale-toronto/).

4. Except for Tibetans who are public figures, I have used first names only, which are all very common in the Tibetan community, and have avoided precise references to date or location, so as to preserve the anonymity of the interviewees.

5. To my knowledge, only Masters' student Jennifer Logan and renowned Tibetologist Carole McGranahan have so far conducted field research in the Tibetan community of Parkdale (Logan 2010; Logan and Murdie 2016; McGranahan 2018).

6. See https://www.bhutilakarpoche.ca/ and https://www.ola.org/en/members/all/bhutilakarpoche.

7. See https://www.facebook.com/KalsangDolmaTO/.

8. See https://www.youtube.com/watch?v=xTiIzeC5pVc for the first interview (October 30, 2018). This interview can also be found with a short presentation of Kalsang Dolma on the Dancing Yacks website: https://dancingyaks.com/toronto-tibetan-ran-for-municipal-election/. See https://www.youtube.com/watch?v=HeBGEQiN20Q for the second interview (November 8, 2018).

9. See https://www.voatibetanenglish.com/a/2483464.html.

10. I found articles on Bhutila Karpoche, Kalsang Dolma or Gelek Badheytsang in three local newspapers and magazines, i.e. Toronto Star, the Globe and Mail and NOW, as well as in one Tibetan magazine published in exile, the Tibetan Journal (in English).

11. This project to resettle 1,000 Tibetans from India and Nepal to the United States started in 1990. By the time it ended in 1998, a total of 5,000 Tibetans had resettled in the United States thanks to family reunion schemes.

12. See https://tibet.ca/en/tibet_and_canada/1000_new_tibetans and https:// www.facebook.com/tibetresettlementproject to follow the journey of the 1,000 Tibetans who have been resettled to Canada through the 1,000 Project.

13. I use the two notions of field and arena alternatively in this article. Developed respectively by Neil Fligstein and Doug McAdam and by James Jasper and Jan Duyvendak, both notions are in my view similar enough for the purposes of this discussion. Neil Fligstein and Doug McAdam acknowledge "substantial affinity" with Pierre Bourdieu, from whom the notion of field is borrowed. Their general theory of social order however strives to overcome the limits identified in previous approaches, such as, in Pierre Bourdieu's case, a silence on the emergence of fields and an overemphasis on the individual at the expanse of collective actors, which is regarded as an important limit to the study of collective action (Fligstein and McAdam 2011:19-20). James Jasper and Jan Duyvendak have replaced field by arena to emphasize a theoretical evolution, but 
are similarly indebted to Pierre Bourdieu (Jasper 2006:142 note 1; Jasper 2012:20; Jasper and Duyvendak 2015:17-18, and notes 7 and 8). Their model tries to overcome more specifically two problems inherent in the use of field, i.e. a conflation of players and arenas and a zero-sum competition.

14. There are several different fields, all embedded in complex webs of other fields, in which players interact. Neil Fligstein and Doug McAdam distinguish three types of interactions between fields: distant and proximate, vertical and horizontal, as well as state and non-state (Fligstein and McAdam 2011:8; see also Fligstein and McAdam 2012:18-19).

15. See https://www.youtube.com/watch?v=xTilzeC5pVc.

16. See https://www.tccegc.org/ and https://www.facebook.com/TCCC.GC/.

17. Lhakar is a political movement that appeared in Tibet in 2008 following the Tibetan uprising against Chinese rule in the context of the 2008 Beijing Olympics (Dorjee 2013).

18. See https://studentsforafreetibet.org/about/ and https://www.sftcanada.org/.

19. Yudon, vice-president of Tibetan Children's Project (TCP) (http:// tibetanchildrensproject.org/tag/tibetan-childrens-project-canada/) is another example encountered during my fieldwork.

20. He still sometimes blogs on Tibetan issues. He recently added a commentary on the Lion's Roar website after the Dalai Lama's controversial interview with BBC journalist Rajini Vaidyanathan (Badheytsang 2019).

21. See https://drebu.wordpress.com/drebu/.

22. See https://www.youtube.com/watch?v=wxAt5TyisZw for Kalsang Dolma and refer to the article published in Toronto Star for Bhutila Karpoche (Ngabo 2019).

23. See http://www.selfhelp.on.ca/2014/04/parkdale-community-information-centre/.

24. See her profile on the Parkdale Community Legal Services webpage: https:// www.parkdalelegal.org/about/board-of-directors/.

25. See her profile on a Ryerson University webpage: https://www.ryerson.ca/socialjustice/ social-justice-week/2017/10/working-so-hard-still-so-poor/.

26. The two articles published by $C B C$ in February 2019 focused not on the fact that she was the first Tibetan to be elected student president of a Canadian university, but on the hateful comments she got and the 10,000 strong-petition asking her to step down, all of which were attributed to Chinese living in Canada, if not to China itself.

27. See https://www.bhutilakarpoche.ca/.

28. All the issues she supported are listed by date on her official website in a four-page long rubric entitled "The latest on the issues." See https://www.bhutilakarpoche.ca/latest_news.

29. See https://www.bhutilakarpoche.ca/tibetan-heritage-month.

30. E.g. Radio Free Asia (RFA) (https://www.youtube.com/watch?v=e5aY-Ay4W4U), Phayul (Lhamo 2020) and the Tibetan Review (Tibetan Review 2020).

31. See https://tibet.net/ontario-legislature-passes-historic-bill-to-recognise-july-as-tibetanheritage-month-tabled-by-mpp-bhutila-karpoche/.

\section{ABSTRACTS}

This article investigates the political mobilization of Tibetans in Toronto. I develop the hypothesis that Tibetans in Toronto who enter into local politics are already politicized, which 
facilitates the transition from activism within the Tibetan community to activism in Canadian society. To explore this transition from an inward- to an outward-looking type of mobilization, I draw on theoretical insights about the political integration of migrants developed by leading scholars in Social Movement Studies and Diaspora Studies. The careers of the two Tibetans who stood for office in Toronto in 2018, Bhutila Karpoche and Kalsang Dolma, as well as of Tibetan blogger and campaign manager Gelek Badheytsang, then serve to analyze the "strategic action fields" (Fligstein and McAdam 2012) or "arenas" (Jasper and Duyvendak 2015) invested by the Tibetans who choose to enter into local politics.

\section{INDEX}

Keywords: political mobilization, local politics, strategic action fields, Tibetan diaspora, Toronto

\section{AUTHOR}

\section{ANNE-SOPHIE BENTZ}

Associate Professor in South Asian History, Université de Paris / CESSMA, Fellow of the Institut Convergences Migrations 